\title{
THE MANAGEMENT OF SPEECH: DISCRETION AND RIGHTS
}

Discretion is pervasive in our legal system, and yet we scarcely know what it is. Ronald Dworkin, for example, has compared discretion to "the hole in the doughnut." Dworkin's metaphor is unsettling because it so precisely captures our instinctive sense of discretion as dead analytic space.

Discretion most often appears to us as merely the negative reflection of the law. It subsists in the interstices of the law. "Where the law ends," Kenneth Davis writes, "discretion begins." 2 It is as if law and discretion were binary opposites, as if the presence of one signaled the absence of the other. We can have law or discretion, but not both. And this is because, as Herbert Packer put it, "The basic trouble with discretion is simply that it is lawless, in the literal sense of that term."3

The difficulty with this view is that it blinds us to the subtle and various ways in which law and discretion are in fact related. Discre-

Robert C. Post is Acting Professor of Law, University of California, Berkeley.

AuthoR's NoTe: I wish to thank Jan Vetter, Paul Mishkin, Owen Fiss, and David Cope for their patience, advice, and assistance. The usual disclaimer that all errors are the author's own is more than usually applicable.

${ }^{1}$ DWORKIn, TAKING Rights SERIOUSLY (1978).

2 Davis, Discretionary Justice: A Preliminary Inquiry 3 (1969).

3 Packer, The Limits of the Crininal Sanction 290 (1978). The notion that law and discretion are simply binary opposites has a long intellectual pedigree. In modern times it can be traced to sources as diverse as Dicey's vision of the Rule of Law, see DICEY, THE LAW OF THE CONSTITUTION 215 (1885), and Weber's conception of "rational-legal" authority, see Nonet \& Selznick, Law and Society in Transition 64 (1978). See, e.g., Gr. Brit. Committee on Administrative Tribunals (Franks Committee), Report, Comd. No. 218, at 6 (1957); HAYEK, THE ROAD TO SERFDOM 72-73 (1944); DickINSON, ADMINISTRATIVE JUSTICE AND THE SUPREIACY OF LAW IN THE UNITED STATES 126 (1927); MaSHAW, BUREALCRATIC JUSTICE 1-2 (1983).

(C) 1985 by The University of Chicago. All rights reserved.

$0-226-46437-7 / 85 / 1984-0063 \$ 01.00$ 
tion is not simply the negative reflection of law, and if we persist with such a vision, we truncate our understanding of important and complicated occasions when law authorizes the exercise of discretion. This is particularly true when litigants seek to curb the management of government institutions by the assertion of constitutional rights. In such circumstances the demands of law and of discretion are at their greatest, as is the necessity of accurately comprehending the relationship of one to the other.

This was demonstrated in the 1983 Term in Seattle Times Co. v. Rbinebart ${ }^{4}$ a case concerned with the constitutional rules governing protective orders that prohibit the disclosure of information received in civil discovery. On one side was the First Amendment right to be free from restraints on speech. On the other was the need for flexibility in the management of pretrial discovery. The Supreme Court perceived the case as a choice between law, with its attendant rules and rights, and discretion, with its attendant flexibility and effectiveness. The Court opted for discretion.

The decision placed the Court at odds with a long line of precedents holding that discretion in the suppression of First Amendment rights is particularly suspect. The most striking aspect of the Court's opinion is its refusal to address this tension, which suggests that the Court lacked an underlying theory of the relationship between First Amendment rights and government discretion. If law and discretion are viewed as irreconcilable, such a theory is impossible. But if law and discretion are instead seen as complementary, one can develop what the Court in Rbinebart so clearly needed: a theory of the management of speech.

\section{Prologue: A Brief Introduction to Civil Discovery, RESTRAINING ORDERS, AND THE FIRST AMENDMENT}

Modern civil discovery was created by the Federal Rules of Civil Procedure of 1938. In a "striking and imaginative departure from tradition," the Rules divested pleadings of their previous functions of "issue-formulation and fact-revelation," and assigned

\footnotetext{
${ }^{4} 104$ S.Ct. 2199 (1984).
}

${ }^{5}$ Proposed amendments to the Federal Rules of Civil Procedure, Advisory Committee's Explanatory Statement concerning Amendments of the Discovery Rules, 48 F.R.D. 487 (1970). 
these functions instead to a new pretrial "deposition-discovery process." This process was to be conducted in the first instance by the litigants themselves, ${ }^{7}$ who were to be provided with powerful "instruments" of information acquisition. ${ }^{8}$ It was to be supervised by the trial judge, who was clothed "with full discretionary power to stop the use of the discovery weapons for harassment or other ulterior motives."

Included in this discretionary authority was the power to issue protective orders prohibiting disclosure of information gained through discovery. ${ }^{10}$ Such restraining orders ${ }^{11}$ had many uses. They could prevent unnecessary disclosure of trade secrets or other confidential information; they could reduce the incentive to abuse discovery processes by seeking information for purposes unrelated to the litigation. As the philosophy of the Rules grew nationally predominant, ${ }^{12}$ restraining orders became commonplace in both state and federal courts. ${ }^{13}$

\footnotetext{
${ }^{6}$ Hickman v. Taylor, 329 U.S. 495, 500-01 (1947). See Pike \& Willis, Tbe New Federal Deposition-Discozery Procedure, 38 Collik. L. REv. 1179, 1436 (1938).

7 "To the extent possible, discovery should take place through procedures instituted and carried out by the parties without judicial intervention." Advisory Committee on Civil Rules, "Topic Disc.-3, The Extrajudicial Operation of Discovery: A Tentative Approach toward Improvement" (Oct. 8, 1963), at 1. See Brazil, Improving Judicial Controls over the Pretrial Development of Civil Actions: Model Rules for Case Management and Sanctions, A.B.F. RESEARCH J. 873, 881-82.
}

${ }^{8}$ Hickman v. Taylor, 329 U.S. at 501.

'Holtzoff, The Elimination of Surprise in Federal Practice, 7 VAND. L. REv. 576, 580 (1954). The first circulated draft of the federal rules contained "practically no provisions for protection" against discovery abuse, but, after "a storm of protest arose all over the country," "novel" powers to supervise discovery were incorporated into Rule 30(b). Federal Rules of Civil Procedure: Proceedings of the Institute at Washington, D.C. 138 (1938); id. at Cleveland, at 287; Preliminary Draft of Rules of Civil Procedure for the District Courts of the United States and the District of Columbia (May 1936). Rule 30(b) was thought to give trial courts "sufficient control" to protect the discovery process from misuse. Institute at Washington, at 99.

${ }^{10}$ Authority to issue such protective orders is currently found in Rule 26(c).

"In discovery systems modeled on the federal rules, the term "protective order" is ordinarily used to refer to the various orders, authorized by Fed. R. Civ. P. 26(c), by which a trial judge exercises control over the discovery process. Such orders can range from limiting or curtailing discovery to placing specified terms and conditions on discovery. For the sake of clarity, I shall use the term "restraining order" to refer to the specific kind of protective order that prohibits litigants and their attorneys and agents from disclosing to third parties information received in discovery.

12 Lolisell, Hazard, \& Tait, Pleading and Procedlre 27 (5th ed. 1983).

${ }^{13}$ See Marcus, Myth and Reality in Protective Order Litigation, 69 CoRnelL L. REv. 1 (1983). Judge Edward Becker recently observed that he was "unaware of any case in the past half- 
Under the Rules the power to issue restraining orders was circumscribed only by the vague legal requirement of "good cause,"14 which freed trial judges from "hard and fast rules" 15 and thus permitted "complete control" over the discovery process through the exercise of "enlightened discretion . . . to decide what restrictions may be necessary in a particular case." 16 Although restraining orders were designed to suppress speech by litigants and their attorneys, they were not thought to pose any particular First Amendment problem. ${ }^{17}$

This comfortable system of judicial management became suspect in 1979, when the District of Columbia Circuit, speaking through Judge David Bazelon, decided In re Halkin. ${ }^{18}$ In a closely reasoned opinion, Judge Bazelon argued that restraining orders pose "many of the dangers of a prior restraint" and thus require "close scrutiny of [their] impact on protected First Amendment expression." $19 \mathrm{Hal}$ kin transposed conventional First Amendment principles into the

dozen years of even a modicum of complexity where an umbrella protective order . . . has not been agreed to by the parties and approved by the court." Zenith Radio Corp. v. Matsushita, $529 \mathrm{~F}$. Supp. 866, 889 (E.D. Pa. 1981). For examples of restraining orders issued in state courts, see Curtis, Inc. v. District Court, 186 Colo. 226, 526 P.2d 1335 (1974); Professional Microfilming, Inc. v. Houston, 661 S.W.2d 767 (Tex. Ct. App. 1983); Wagner Iron Works v. Wagner, 4 Wis. 2d 228, 90 N.W.2d 110, 117 (1958); Bee Chemical v. Service Coatings, Inc., 116 Ill. App. 2d 217, 253 N.E.2d 512, 514 (1969). Restraining orders can vary widely in their provisions. Compare Tavoulareas v. Prio, 93 F.R.D. 24, 33-35 (D.D.C. 1981), with Manual for CoNiplex litigation, pt. 2, $\$ 2.50$, at 357 (5th ed. 1982), reprinted in 1 MOORE'S FEDERAL PRACTICE, pt. 2, at 354-59 (2d ed. 1982) (hereinafter cited as MANUAL fOR CoMplex Litigation), with In Re Coordinated Pretrial Proceedings in W. Liquid Asphalt Cases, 18 Fed. R. Serv. 1251 (N.D. Cal. 1974).

${ }^{14}$ See Fed. R. Civ. P. 26(c). Virtually every state permits restraining orders to be issued upon a showing of "good cause."

15 Zenith Radio Corp. v. Matsushita, 529 F. Supp. at 891

${ }^{16}$ Wright \& Miller, Federal Practice and Procedure: Civil $\$ 2036$ (1970).

${ }^{17}$ In 1963, for example, the Second Circuit, speaking through Friendly, J., summarily rejected a First Amendment challenge to a protective order enjoining litigants from "publishing or disclosing to any third party" certain information acquired in discovery. International Products Corp. v. Koons, 325 F.2d 403. See also Rodgers v. U.S. Steel Corp., 536 F.2d 1001, 1006 (3d Cir. 1976). Judge Friendly stated simply: "[W]e entertain no doubt as to the constitutionality of a rule allowing a federal court to forbid the publicizing, in advance of trial, of information obtained by one party from another by use of the court's processes." 325 F.2d at 407.

${ }^{18} 598$ F.2d 176 (D.C. Cir. 1979).

${ }^{19} \mathrm{Id}$. at 186 . The holding in Halkin was anticipated by a decision in the Southern District of New York to the effect that a restraining order was a "prior restraint" and thus unconstitutional. Reliance Ins. Co. v. Barron's, 428 F. Supp. 200 (S.D.N.Y. 1977). See also Davis v. Romney, 55 F.R.D. 337 (E.D. Pa. 1972). 
context of civil discovery, and concluded that the constitutionality of a restraining order should rest on three requirements: "the harm posed by dissemination must be substantial and serious; the restraining order must be narrowly drawn and precise; and there must be no alternative means of protecting the public interest which intrudes less directly on expression."20

Halkin provoked immediate and vigorous reaction. ${ }^{21}$ The impact of the decision stemmed from its conclusion that restraining orders could not be analyzed independent of the First Amendment. The opinion was controversial because the "rigorous standard" it established was thought to curtail the ability of trial judges "to regulate abuses once the discovery process has started." 22 Precisely at the moment when a growing perception of a discovery "crisis"23 was provoking calls for greater "personal supervision and management by the trial Judge, ${ }^{24}$ Halkin appeared to deny judges the flexibility necessary for such management. ${ }^{25}$

The logic of Halkin, however, proved difficult to fault. One line of attack was to redefine and diminish the First Amendment interests at issue. But there did not seem to be a convincing alternative analysis of litigants' First Amendment interests, and widely varying and implausible approaches were advanced. The nature of First

$20598 \mathrm{~F} .2 \mathrm{~d}$ at 191.

21 For discussion of the case, see Marcus, note 13 supra; Note, Rule 26(c) Protective Orders and the Fint Amendment, 80 Colcui. L. REv. 1645 (1980); Note, Tbe Finst Amendment Rigbt to Disominate Discovery Materials: In Re Halkin, 92 HARv. L. ReV. 1550 (1979); Comment, Protective Orders Probibiting Dioemination of Discovery Information: The Fint Amendment and Good Cause, 1980 Duke L.J. 766; Recent Decision, 48 CIN. L. REv. 900 (1979); Note, Finst Amendment Interests in Trade Secrets, Private Materials, and Confidential Informatian: The Use of Protective Orders in Defamation Litigation, 69 Iowa L. REv. 1011 (1984); Note, Constitutional Standards Governing Isouance of Protective Orders Purwant to Fed. R. Civ. P. 26(c) Wben Freedom of Speech Is Restrained-In Re Halkin 598 F.2d 176 (D.C. Cir. 1979), 52 TEMP. L.Q. 1197 (1979).

22 Note, The Fint Amendment Rigbt to Dioieminate Discovery Materials, note 21 supra, at 1559.

${ }^{23}$ See Herbert v. Lando, 441 U.S. 153, 176-77 (1979); Amendments to Federal Rules of Civil Procedure, 85 F.R.D. 521 (1980) (Powell, J., dissenting). For a narrative of the development of the discovery "crisis," see Nordenberg, Tbe Supreme Court and Discovery Reform: Tbe Continuing Need for an Umpire, 31 SyRaCuse L. REV. 543 (1980).

24 Pollack, Discovery-Its Abuse and Correction, 80 F.R.D. 219, 223 (1977). See Schwarzer, Managing Civil Litigatian: Tbe Trial Judge's Role, 61 JUDICATURE 400 (1978); Rosenberg \& King, Curbing Discovery Abuse in Civil Litigation: Enougb Is Enougb, 1981 B.Y.U. L. REV. 579; MANUAl. for Complex LiTigation, $\$ 1.10$ ("Judicial Control of Complex Cases"), at 1719.

25 See Marcus, note 13 supra, at 23-27; Koster v. Chase Manhattan Bank, 93 F.R.D. 471 , 475-80 (S.D.N.Y. 1982). For a contrary view, see Brink v. DaLesio, 82 F.R.D. 664, 677 (D. Mid. 1979). 
Amendment interests was said to turn on whether discovered information was admissible at trial; ${ }^{26}$ on whether information was discovered from the government or from a private party ${ }_{;}^{27}$ on whether information discovered was "commercial" or "near the heart of the information protected by the First Amendment."28 It was also said that since discovery itself was a matter of grace which could be terminated at the discretion of the trial judge, litigants had only de minimis First Amendment rights in disseminating information gained through discovery. ${ }^{29}$ Although the last approach was compatible with great judicial flexibility, it was not widely accepted because of its apparent resurrection of the "right-privilege" distinction putatively discarded by the Supreme Court. ${ }^{30}$

An alternative line of attack was to emphasize the importance of the government's interests in maintaining discretionary control over the discovery process. This approach, taken in tandem with the first, led some courts to an amorphous "balancing test" in which "the ttial court's broad discretion to impose protective orders for good cause" was preserved. ${ }^{31}$ It led one circuit to a "standard of 'good cause' that incorporated a 'heightened sensitivity' to the First Amendment concerns at stake." 32 Tests proliferated, ${ }^{33}$ and it soon

\footnotetext{
${ }^{26}$ See In re San Juan Star Co., 662 F.2d 108, 115 (1st Cir. 1981).

${ }^{27}$ See In re Agent Orange Product Liability Litigation, 99 F.R.D. 645, 649 (E.D.N.Y. 1983). Ill.).

${ }^{28}$ See Magnavox Co. v. Mattell, Inc., No. 80-C-4124, slip op. (March 24, 1981, N.D.

${ }^{29}$ See In re Halkin, 598 F.2d at 206-07 (Wilkey, J., dissenting); Note, The Fint Amendment Right to Disseminate Discovery Materials, note 21 supra, at 1552-57.

${ }^{30}$ See In re Halkin, 598 F.12d at 190; In re San Juan Star, 662 F.2d at 114; Zenith Radio Corp. v. Matsushita, 529 F. Supp. at 911; Recent Decision, 48 Geo. WASH. L. REv. 486, 502-04 (1980). So great was the divergence of approaches, that a consensus emerged only for the propositions that litigants' First Amendment rights did not terminate automatically with the commencement of litigation; that such rights were not "waived" simply by choosing to engage in discovery; and that attorneys retained First Amendment rights despite their positions as officers of the court. See Koster v. Chase Manhattan Bank, 93 F.R.D. at 475-76. Halkin's reasoning on these points was persuasive. See $598 \mathrm{~F} .2 \mathrm{~d}$ at $186-90$.

${ }^{31}$ Zenith Radio Corp. v. Matsushita, 529 F. Supp. at 911; Air Tec Associates, Inc. v. Cottman Transmission Systems, Inc., 1980-2 Trade Cases, If 63,560 (E.D. Pa. 1980).

${ }^{32}$ In re San Juan Star, 662 F.2d at 116.

${ }^{33}$ One commentator, for example, found guidance in the Court's decision in Pickering v. Board of Education, 391 U.S. 563 (1968), and proposed a "Pickering-type balancing test." Comment, note 21 supra, at 791. Another, with some prescience, found Procunier v. Martinez, 4167 U.S. 396 (1974), controlling and offered a different balancing test. Note, Rule
} 
became apparent that the problem was the absence of an underlying theoretical framework within which a convincing analysis could be developed.

In the midst of this disarray the Supreme Court granted certiorari in a case that exemplified the confusion, Rbinehart $v$. Seattle Times Co ${ }^{34}$ Rbinebart was an en banc decision of the Supreme Court of Washington, holding that under state rules of civil procedure trial judges had "broad discretion" to issue restraining orders. ${ }^{35}$ The Washington Court had concluded that even if a restraining order were assumed to constitute a "prior restraint of free expression" requiring a " "heavy burden' of justification," discretionary authority to issue such an order was nevertheless justified by the "interest of the judiciary in the integrity of its discovery processes." 36

\section{Seattle Times Co. V. Rhinehart: The Reasoning AND STRUCTURE OF THE COURT'S OPINION}

Rhinebart was an eccentric case. It involved the Aquarian Foundation, a "spiritualist Church" that believed in "the ability to communicate with deceased persons through a medium." 37 The

26(c) Protective Orders and the Fint Amendment, note 21 supra. Several courts and commentators approved the strict Halkin test. See, e.g., National Polymer Products, lnc. v. BorgWarner, 641 F.2d 418, 424-25 (6th Cir. 1981); Farnum v. G. D. Searle \& Co., 339 N.W.2d 384, 389-90 (lowa 1983); Comment, 55 Notre DaMe LAW. 424, 434-35 (1980); Comment, 21 WM. \& MARY L. REV. 331, 354-55 (1979); Note, 56 CHI. KENT L. ReV. 943 (1980); $c f$. Kuiper v. District Court, 632 P.2d 694, 697-98 (Mont. 1981). Some commentators advocated a test stricter than Halkin. See Recent Decision, note 30 supra, at 506-08; Note, Constitutional Standards Governing Isuance of Protective Orders, note 21 supra, at 1218. Two decisions, both involving newspapers, appear to have adopted an absolute standard, striking down restraining orders as prior restraints. Georgia Gazette Pub. Co. v. Ramsey, 248 Ga. 528, 284 S.E.2d 386, 387 (1981); Vara v. Gore Newspapers, 8 Med. L. Rptr. 2231 (Fla. Cir. 1982).

${ }^{34} 98$ Wash. 2d 226, 654 P.2d 673 (1982).

${ }^{35}$ Id. at 677.

${ }^{36}$ Id. at 690 . This conclusion was almost certainly incorrect. If even in time of war the federal government could not overcome the "heavy presumption" against prior restraints to have enjoined the publication of stolen classified documents, New York Times Co. v. United State, 403 U.S. 713,714 (1971), then surely this presumption could not be overcome by the trial judge's restraining order in Rbinebart, which had been issued without findings and in response to only the most general claims of confidentiality. $2-3$.

${ }^{37}$ The Scattle Times Co. v. Rhinehart, No. 82-1721 (U.S. Sup. Ct.), Brief of Resp., at 
"primary mental and physical medium" of the Church was Reverend Rhinehart, who claimed to "transfer . . . objects from one place or time" to another ${ }^{38}$ and to "apport" precious stones from his body. ${ }^{39}$ Aggrieved by a series of skeptical articles published in the Seattle Times and the Walla Walla Union-Bulletin, Rhinehart, the Foundation, and several church members brought an action in Washington Superior Court for libel and invasion of privacy. ${ }^{40}$ Alleged injuries included declining donations and membership. ${ }^{+1}$

Defendants in the suit sought discovery concerning the Foundation's financial condition and the identity of its members. ${ }^{42}$ Plaintiffs resisted, claiming that as a small and unpopular religion they were subject to persecution in the community at large, and hence that forced disclosure of the requested information would infringe their constitutional rights of association and religion. ${ }^{43}$ ln the alternative, plaintiffs moved for the issuance of a restraining order prohibiting dissemination of the requested information. ${ }^{4+}$ After receiving affidavits alleging that violent threats and incidents had been caused by prior articles in the newspapers, the trial judge compelled the discovery and issued the restraining order. ${ }^{45}$ The order

\footnotetext{
${ }^{38}$ Ibid.

${ }^{39}$ The Seattle Times v. Rhinehart, No. 82-1721 (U.S. Sup. Ct.), Joint Appendix (hereinafter cited as J.A.), at 20a.

${ }^{40}$ Named as defendants were the Seattle Times Company, which published both the Seattle Times and the Union-Bulletin, and several individual reporters associated with the articles.
}

${ }^{41}$ J.A. at I1a; 104 S.Ct. 2199, 2203 n.2 (1984).

42 The discovery provisions of the Washington rules, like those of most states, are modeled after the Federal Rules of Civil Procedure. Liberal discovery is permitted not only of directly relevant information likely to be admissible at trial, but also of information "reasonably calculated to lead to the discovery of admissible evidence." See Wash. Super. Ct. Rule 26(b)(1); Trust Fund Services v. Aro Glass Co., 89 Wash. 2d 758, 575 P.2d 716, 719 (1978).

${ }^{43}$ At the time they made this claim, plaintiffs had already produced to defendants Rhinehart's tax returns, as well as a number of other financial documents. 104 S.Ct. at 2203.

44 The basis for plaintiffs' motion for a restraining order was Wash. Super. Ct. Rule 26(c), which is virtually identical to its federal counterpart Rule 26(c).

${ }^{45}$ Although the trial judge's opinion is rather ambiguous, it appears that he decided to issue the restraining order because he concluded that it would constitute an "abuse of discovery" to use the court's processes to acquire information that would "normally be kept confidential" and then to publish that information in the news media. J.A. at 51a-54a. In issuing the order, the judge did not refer to plaintiffs' affidavits, or to any other facts in the record. He apparently believed that the only factual predicate necessary for the issuance of the order was that the newspapers intended to publicize information that plaintiffs regarded as confidential. 
was ambiguous as to its scope, ${ }^{46}$ and the judge made no effort to support it by findings of fact. ${ }^{47}$

The order was affirmed by the Supreme Court of Washington in an opinion which strongly argued that restraining orders were a necessary concomitant of a system of liberal discovery. The court noted that without the assurance provided by restraining orders, information produced in discovery "will be used only for the legitimate purposes of litigation," litigants concerned with publicity might be tempted to "withhold information" or "to shade the truth," or even to "forego the pursuit of their just claims." 48

Even the Halkin decision, however, had acknowledged that restraining orders were important for "the effective functioning of the civil discovery system." 49 But the Washington court, unlike the D.C. Circuit, believed that "the integrity of the discovery process" could be protected only if trial judges were free to exercise "a broad discretion to manage the discovery process in a fashion that will implement the goal of full disclosure of relevant information and at the same time afford the participants protection against harmful side effects." 50 Thus while the Halkin court would permit the is-

* The relevant provisions of the restraining order state: "2. Plaintiffs' motion for a protective order is granted with respect to information gained by the defendants through the use of all of the discovery processes regarding the financial affairs of the various plaintiffs, the names and addresses of Aquarian Foundation members, contributors, or clients, and the names and addresses of those who have been contributors, clients, or donors to any of the various plaintiffs. 3. The defendants and each of them shall make no use of and shall not disseminate the information defined in paragraph 2 which is gained through discovery, other than such use as is necessary in order for the discovering party to try the case. As a result, information gained by a defendant through the discovery process may not be published by any of the defendants or made available to any news media for publication or dissemination. This protective order has no application except to information gained by the defendants through the use of discovery processes." 104 S.Ct. at 2204 n.8. The'restraining order is thus ambiguous with respect to scope, because it is not clear whether it applies only to information "regarding the financial affairs of the various plaintiffs [and] the names and addresses of [plaintiffs'] members, contributors or clients," as described in paragraph 2 of the order, or whether it applies to all "information gained by a defendant through the discovery process," as described in paragraph 3 of the order. The Washington Supreme Court referred to the order twice, once as if it applied to all information received in discovery, $654 \mathrm{P} .2 \mathrm{~d}$ at 675 , and once as if it applied only to the specific information described in paragraph 2.654 P.2d at 690.

${ }^{47}$ See note 45 supra.

${ }^{48} 654$ P.2d at 689 . Apart from the instrumental effects of restraining orders on the system of pretrial discovery, the court also noted that they served to implement the state's interest in protecting "citizens in their legitimate expectations of privacy." Id. at 688. See id. at 679-80.

4) 598 F.2d at 192.

s0 654 P.2d at 689,677 . 
suance of a restraining order only if a trial judge considered and made "the necessary findings on each element" of the appropriate First Amendment standard, ${ }^{51}$ the Washington Supreme Court found these restrictions "unduly complex and onerous" to achieve "the objectives of pretrial discovery." 52 It disparaged "the difficulties which . . . trial courts create for themselves when they attempt to enunciate restrictive criteria for the exercise of their discretion." 33 The Washington court concluded that the management of pretrial discovery could constitutionally be accorded the flexibility necessary to attain its ends. The issuance of restraining orders was to be "singularly within the discretion of the trial court" and reversible "only on a clear showing of abuse of discretion." 54

As the case came to the Supreme Court of the United States, therefore, it was susceptible to several narrow resolutions. The Court could have found the restraining order before it justified because of plaintiffs' constitutional interests in freedom of association and religion, or because the affidavits in the record graphically detailed dangers of actual physical harm. Conversely, the Court could have found the restraining order constitutionally unjustified because of its ambiguity, or because it was not grounded in findings of fact. ${ }^{55}$ But the Court avoided these narrow approaches and instead affirmed the Washington court on the broadest possible grounds.

In a terse and unanimous opinion, the Court, speaking through Justice Powell, held that although litigants had First Amendment rights in the dissemination of information gained through discovery, the State's "substantial interest in preventing . . . abuse of its

${ }^{51} 598$ F.2d at 192.

52654 P.2d at 685 .

${ }^{53}$ Id. at 684 .

${ }^{54}$ Id. at 678 .

${ }^{55}$ There is a developing case law interpreting the "good cause" requirement of Fed. R. Civ. P. 26(c) to require "a particular and specific demonstration of fact, as distinguished from stereotyped and conclusory statements." WRIGHT \& M1LLER, note 16 supra, $\$ 2035$ at 265. See Gulf Oil Co. v. Bernard, 452 U.S. 89, 102 n.16 (1981); General Dynamics Corp. v. Selb Mfg. Co., 481 F.2d 1204, 1212 (8th Cir. 1973); Zenith Radio Corp. v 3 Matsushita, 529 F. Supp. at 891; United States v. Hooker Chemical \& Plastics Co., 90 F.R.D. 421, 425 (W.D.N.Y. 1981); Parsons v. General Motors Corp., 85 F.R.D. 724, 726 (N.D. Ga. 1980); Argonaut Ins. Co. v. North American Co. for Property and Casualty Ins., slip op., No. 76 Civ. 802 (Dec. 9, 1980, S.D.N.Y.). These holdings, however, are not constitutional in nature. 
processes" justified delegation of "broad discretion on the trial court to decide when a protective order is appropriate and what degree of protection is required." There was to be "no heightened First Amendment scrutiny." 56

This conclusion was clearly designed to terminate the turmoil created by Halkin. But the price of this achievement was to place the Court at odds with a long line of precedents holding that the First Amendment deeply disfavors "official discretionary power to control" speech ${ }^{57}$ in the absence of "narrowly drawn, reasonable and definite standards for the officials to follow." 58 Only six days before Rhinebart, the Court had reaffirmed its commitment to the rule that statutes creating discretionary authority to suppress speech are facially unconstitutional, since "every application of the statute create[s] an impermissible risk of the suppression of ideas."

This tension between First Amendment rights and official discretion is never acknowledged in Justice Powell's opinion. The silence is strange, and gives the impression that the issue was avoided because the Court lacked a conceptual scheme within which it could be analyzed. Instead the Court struggled to justify its conclusion using conventional doctrinal formulations that were inconsistent with the exercise of official discretion.

\section{A. THE PROCUNIER TEST}

At the outset of its opinion the Court announced, without further explanation, that the constitutionality of Washington's Rule 26(c), which authorizes the issuance of restraining orders, ${ }^{60}$ would turn on ${ }^{61}$

\footnotetext{
56 Seattle Times Co. v. Rhinehart, 104 S.Ct. 2199, 2209 (1984). Although Justice Brennan joined Justice Powell's opinion, he also wrote two brief concurring paragraphs in which he said that he would affirm the judgment of the Washington court because plaintiffs' "interests in privacy and religious freedom are sufficient to justify this protective order and to overcome the protcctions afforded free expression by the First Amendment." 104 S.Ct. at 2210. Justice Brennan's opinion was joined by Justice Marshall.

57 Kunz v. New York, 340 U.S. 290, 293 (1951).

${ }^{58}$ Nietmotko v. Maryland, 340 U.S. 268, 271 (1951). See Shuttlesworth v. City of Birmingham, 394 U.S. 147, 150-51 \& n.2 (1969); Saia v. New York, 334 U.S. 558 (1948); Hague v. CIO, 307 U.S. 496 (1939); Lovell v. Griffin, 303 U.S. 444 (1938).

${ }^{50}$ Members of City Council v. Taxpayers for Vincent, 104 S.Ct. 2118,2125 \& n.15 (1984).

${ }^{\infty}$ See note 44 supra.

G1 104 S.Ct. at 2207.
} 
whether the "practice in question [furthers] an important or substantial governmental interest unrelated to the suppression of expression," and whether "the limitation of First Amendment freedoms [is] no greater than is necessary or essential to the protection of the particular governmental interest involved." Procunier v. Martinez, 416 U.S. 396, 413 (1974); see Brown v. Glines, 444 U.S. 348, 354-55 (1980); Buckley v. Valeo, 424 U.S. 1, 25 (1976).

The two-part test derives from Procunier v. Martinez, an early Powell opinion dealing with the censorship of prisoners' mail. In fashioning the Procunier test, Powell relied explicitly on Chief Justice Warren's opimion in United States v. O'Brien. ${ }^{62}$

The first element of the test concerns whether Rule 26(c) furthers a substantial government interest unrelated to the suppression of expression. The Court argued that Rule 26(c) furthers a substantial government interest in the protection of the "privacy interests of litigants and third parties." ${ }^{13}$ As a preliminary matter, this interest does not appear to be "unrelated to the suppression of expression." Every suppression of speech can be justified in terms of an interest that is speech neutral. A ban on the teaching of anarchy, for example, can be justified on the grounds of domestic security. Therefore a sensible interpretation of the requirement that a government interest be "unrelated to the suppression of expression" must ask, as John Ely does in his discussion of O'Brien, "whether the harm that the state is seeking to avert is one that grows out of the fact that the defendant is communicating, and more particularly out of the way people can be expected to react to his message, or rather would arise even if the defendant's conduct had no communicative significance whatever." 64

In Rbinebart the Court stated that restraining orders were justified because of the government's interest in the protection of privacy interests. But this justification turns precisely on the fact that litigants are communicating. The purpose of Rule 26(c) is to

${ }^{62}$ See Procunier v. Martinez, 416 U.S. 396, 411-14 (1974).

${ }^{63} 104$ S.Ct. at 2208.

${ }^{64}$ Ely, Flag Desecration: A Case Study in the Roles of Categorization and Balancing in Fint Amendment Analysis, 88 HarV. L. ReV. 1482, 1497 (1975). See Tribe, Alierican CoNSTITUTIONAL LAW 580-88 (1978). This is the approach implicitly adopted by the Court in Buckley v. Valeo, 424 U.S. 1 (1976). See also Consolidated Edison Co. v. Public Service Comm'n, 447 U.S. 530,540 n.9 (1980). 
eliminate the consequences of speaking about certain kinds of subjects; if litigants spoke gibberish, so that no one could understand them, privacy interests would not be endangered. For this reason the government's interest cannot be said to be unrelated to the suppression of expression. ${ }^{65}$

More important, however, the Court was unable to employ the Procunier test in an internally consistent manner. This is true for two reasons. First, the Procunier test requires that the "practice in question" further a "substantial" government interest. To justify the issuance of a restraining order, therefore, the privacy interest to be protected must be "substantial." At a minimum this required the Court to create standards by which "substantial" privacy interests could be identified and distinguished from "nonsubstantial" privacy interests. In previous cases the Court has been quite strict in specifying the kinds of privacy interests that could justify suppression of speech. In Cox Broadcasting Corp. v. Cobn, for example, where the Court faced a similar "collision between claims of privacy and those of" freedom of speech, the Court recognized the need for "caution" and carefully crafted a narrow decision stressing the exact nature of the privacy interest sought to be protected by state law. ${ }^{66}$ But the Court made no such effort in Rbinebart. It refused to identify which privacy interests were "substantial" and hence would constitutionally justify the issuance of a restraining order. For this reason the Court could not claim that Rule 26(c) authorized only those restraining orders necessary to protect "substantial" privacy interests. ${ }^{67}$ Consequently, its conclusion that Rule 26(c) satisfied the first element of the Procunier test is simply unsustainable.

Second, the Procunier test required that "the limitation of First Amendment freedoms" be "no greater than is necessary or essential to the protection of the particular governmental interest involved." But if the Court has not specified the nature of the privacy interests

\footnotetext{
as Powell's handling of this question recalls his treatment of the same issue in Proctunier. See 416 U.S. at 413 . In that case the regulation at issue sought to suppress the results of intended communications, and yet Powell viewed it as "speech neutral," thus eviscerating the requirement that the regulation be "unrelated to the suppression of expression."

${ }^{\circ} 420$ U.S. 469,491 (1975).

${ }^{67}$ The requirement that restraining orders only issue to protect substantial privacy interests is not implicit in the "good cause" standard of Rule 26(c), because that standard simply confers discretion on trial courts. See text at notes 14-16 supra.
} 
to be protected, then it would seem in principle impossible to know whether limitations on First Amendment freedoms will be "necessary or essential." The Court's conclusion, moreover, was that it is constitutional to commit the issuance of restraining orders to the broad discretion of trial judges. The Court did not restrict that discretion by requiring trial judges to consider litigants' First Amendment interests. Thus where litigants' First Amendment interests can be accommodated without impairment of government interests, as, for example, where a narrower or more precise restraining order would adequately protect pertinent privacy interests, the issuance of a broader or vaguer restraining order would be both constitutionally proper and inconsistent with the second element of the Procunier test. In the face of these contradictions the Court did not even attempt to claim or argue that Rule 26(c) creates only necessary or essential limitations on the First Amendment rights of litigants. It simply proposed and then abandoned the second element of the Procunier test.

The Court's difficulties in applying the Procunier test ultimately follow from its conclusion that trial courts should have "broad discretion" to decide "when a protective order is appropriate." The Procunier test requires that each decision to issue a restraining order be subject to First Amendment standards designed to measure the weight or importance of the privacy interests to be protected. The Court's refusal to impose such standards is explicable only as a judgment that they would be incompatible with the "broad discretion" that the Court wished to confer on trial courts.

This dilemma could have been softened somewhat if the Court had attempted to justify restraining orders on the basis of a "substantial" government interest that was systemic in nature, as, for example, the government's interest in the supervision of pretrial discovery. Since the importance of such a systemic interest need not be determined on a case-by-case basis, the tension between the application of standards and the exercise of discretion would diminish. But the tension would not disappear altogether, since the question would nevertheless remain whether any particular restraining order was "necessary or essential" to the asserted government interest.

The Court's abandonment of the second element of the Procunier test is thus particularly revealing, for it evinces the Court's extreme reluctance to trammel the exercise of trial court discretion by the 
application of any legal standards. This reluctance is evidence that the Court shared the common belief, "buried deep in the hearts of various constitutional theorists and judges," 68 that there is an "essential incompatibility" between law and discretion. ${ }^{69}$ The Court evidently believed it had to choose between "heightened First Amendment scrutiny" and the "broad discretion" of "the trial court to decide when a protective order is appropriate." It could have one or the other, but not both.

From this perspective, First Amendment rights and government discretion are irreconcilable. "To discipline . . . discretion by rule and rote is somehow to denature it." $"$ One way to break out of this impasse is to reject its premise and to view law and discretion as complementary rather than incompatible. The Court, however, chose not to follow this approach, and instead sought to bolster its opinion by arguing, first, that unfettered trial court discretion was justifiable, and, second, that litigants retained only diminished First Amendment rights in the dissemination of discovery information.

\section{B. THE COURT'S JUSTIFICATION FOR DISCRETION}

Official discretion to suppress speech has generally been viewed as presumptively unconstitutional. In view of the Court's "long line" of decisions consistently striking down as "unconstitutional censorship" those statutes making the exercise of First Amendment rights "contingent" upon the "discretion" of a public official, ${ }^{71}$ one would expect the Court carefully to analyze the particular features of restraining orders that would justify trial court discretion in their issuance. But the Court devoted only one short paragraph to the issue: $^{72}$

We also find that the provision for protective orders in the Washington Rules requires, in itself, no heightened First Amendment scrutiny. To be sure, Rule 26(c) confers broad discretion on the trial court to decide when a protective order is appropriate and

\footnotetext{
${ }^{a s}$ Galligan, The Nature and Function of Policies witbin Discretionary Power, 1976 PLB. L. 332.

${ }^{69}$ Smith, Tboughts on a Britisb Conseil dEtat, 23 PLB. AD. 23, 30 (1945).

${ }^{70} \mathrm{Ibid}$.

${ }^{71}$ Staub v. City of Baxley, 355 U.S. 313, 322 (1958).

72104 S.Ct. at 2209.
} 
what degree of protection is required. The legislature of the State of Washington, following the example of the Congress in its approval of the Federal Rules of Civil Procedure, has determined that such discretion is necessary, and we find no reason to disagree. The trial court is in the best position to weigh fairly the competing needs and interests of the parties affected by discovery. The unique character of the discovery process requires that the trial court have substantial latitude to fashion protective orders.

The passage is disappointing. The rhetoric of "deference" is misleading. Neither Congress nor the Washington legislature had anything to do with the formulation of Rule 26(c). The Washington Rule was in fact issued by the Supreme Court of Washington, which simply copied it verbatim from the federal rule promulgated by the United States Supreme Court. ${ }^{73}$ Ultimately, the Court was simply "deferring" to itself. Moreover, even if the fiction were indulged that the Court were "deferring" to the independent judgment of the Supreme Court of Washington in deciding to reissue Rule 26(c), such deference is inappropriate in a First Amendment context, where the Court has repeatedly held that "deference to a legislative finding cannot limit judicial inquiry when First Amendment rights are at stake."74

The Court's observation that trial judges are in the best position to weigh the "competing needs and interests of the parties" is equally unhelpful. The fact that there are competing interests to be balanced has never, by itself, been thought to require the delegation of "broad" discretion. ${ }^{75}$ And the fact that a trial judge is in the best position to assess the particular situation before him would also

\footnotetext{
${ }^{73}$ See note 44 supra. Pursuant to Wash. Rev. Code $\S 204.190$, Washington rules of civil procedure are promulgated directly by the Supreme Court of Washington and are immediately effective. See Ashley v. Superior Court, 83 Wash. 2d 630, 521 P.2d 711, 715 (1974). Rule 26(c) was ordered into effect by the Washington court in 1972 . 80 Wash. 2d 1191-92 (1972). Pursuant to 28 U.S.C. $\$ 2072$, federal rules of civil procedure are prescribed by the Supreme Court, and become effective ninety days after they have been "reported to Congress by the Chief Justice." Congtess has never altered the formulation of Rule 26(c) or any of its predecessors.

${ }^{74}$ Landmark Communications, Inc. v. Virginia, 435 U.S. 829, 843 (1978). The Court has also noted that in First Amendment cases, less deference is due to the judgments of lower courts than to legislative decisions, since the "judgments below ... do not come to us encased in the armor wrought by prior legislative deliberation." Bridges v. California, 314 U.S. 252, 261 (1941).

${ }^{75}$ Press-Enterprise Co. v. Superior Court, 104 S.Ct. 819, 824 (1984); Nebraska Press Assn. v. Stuart, 427 U.S. 539, 570 (1976).
} 
not seem to be distinctive, since the same could be said in defense of the numerous licensing statutes that the Court has struck down because of their impermissible delegation of discretionary power to local officials. ${ }^{76}$ In each of these cases local officials could, with some plausibility, have claimed to be in the best position to evaluate the competing claims of local interests, and yet the Court has consistently refused to defer to such claims.

One might defend the Court's position on the grounds that discretion in the hands of a trial judge is quite different from and more acceptable than discretion in the hands of a local sheriff. But this argument ultimately rests on the notion that discretion for the local sheriff constitutes a license to engage in political discrimination, whereas discretion for the trial judge is the freedom to obey the law. Thus the argument fails precisely to the extent that the law simply authorizes a judge to exercise discretion, without providing further standards for guidance. Within the field of discretion authorized by law, a judge, like a sheriff, is free to use the suppression of speech as a tool of policy. And while judicial policy, unlike that of local sheriffs, may not involve hostility to unpopular religious sects, it may well involve exaggerated respect for law and social stability. ${ }^{77}$

For this reason the Court has traditionally viewed with disfavor judicial discretion to suppress speech. In Cantwell v. Connecticut, ${ }^{78}$ for example, a Jehovah's Witness who had played a religious phonograph record on the street was convicted of the common-law offense of inciting a breach of the peace. The Court noted that since the conviction was "based on a common law concept of the most general and undefined nature," there was a danger that the government could "unduly suppress free communication of views, religious or otherwise, under the guise of conserving desirable condi-

${ }^{76}$ Thus, for example, in his separate opinion in Kunz v. New York, 340 U.S. 290, 273 (1951), Justice Frankfurter knew the arguments for deference and stated that "this Court should not substitute its abstract views for the informed judgment of local authorities confirmed by local courts." Id. at 284. Frankfurter found these considerations insufficient, however, to sustain the constitutionality of a statute giving local officials broad discretion to grant or deny permits to speak.

${ }^{77}$ It has been said that underlying much First Amendment theory and doctrine is the perception "that judges tend to be unduly risk averse in ruling upon the claims of speakers." Blasi, Tow ards a Tbeory of Prior Restraint: Tbe Central Linkage, 66 MinN. L. Rev. 11, 52 (1981). But see Jeffries, Retbinking Prior Restraint, 92 YALE L.J. 409, 426-27 (1983).

${ }^{78} 310$ U.S. 296 (1940). 
tions." The diffuse common-law standard left "to the executive and judicial branches too wide a discretion in its application." ${ }^{80}$ In the absence "of a statute narrowly drawn to define and punish specific conduct," therefore, judicial discretion was to be controlled by the strict requirements of the clear and present danger test. ${ }^{81}$

A similar distrust of judicial discretion underlies Bridges v. Califor$n i a,{ }^{82}$ in which, relying in part on Cantwell, the Court used the clear and present danger test sharply to curtail common-law judicial discretion to punish by contempt out of court publications tending to interfere with the fair and orderly administration of justice. This same distrust explains the Court's tendency to view with disfavor judicial injunctions that suppress speech and that are based not on specific statutory authorization, but on vague common-law or constitutional norms. ${ }^{83}$ In this respect, the broad discretion given to trial judges to decide "when a protective order is appropriate and what degree of protection is required" creates close structural similarities between restraining orders and those injunctions which the Court has in the past struck down as unconstitutional prior restraints. ${ }^{84}$

${ }^{79} \mathrm{Id}$. at 308 .

${ }^{80} \mathrm{Ibid}$. (emphasis added). See Smith v. Goguen, 415 U.S. 567, 573 (1973).

81310 U.S. at 311.

82314 U.S. 252 (1941).

${ }^{83}$ Compare Nebraska Pres, note 75 supra, New York Times v. United States, 403 U.S. 713 (1971), and Organization for a Better Austin v. O'Keefe, 402 U.S. 415 (1971), with Kingsley Books v. Brown, 354 U.S. 436 (1957), and Pittsburgh Press Co. v. Human Relations Comm'n, 413 U.S. 376 (1973). Cf. United States v. The Progressive, Inc., 467 F. Supp. 990 (W.D. Wis. 1979).

${ }^{84}$ The Court in Rbinebart had a great deal of difficulty distinguishing restraining orders from "the kind of classic prior restraint that requires exacting First Amendment scrutiny." 104 S.Ct. at 2208. The difference, the Court said, lay in the fact that restraining orders prohibit the dissemination only of "that information obtained through use of the discovery process," and permit the publication of "identical information" if "gained through means independent of the court's processes." Ibid. The Court's distinction was an apparent attempt to build on Justice Powell's concurring opinion in Gannett Co. v. DePasquale, 443 U.S. 368 (1979), in which he argued that a judicial order closing a pretrial hearing differed from a "classic prior restraint" because the latter "applied to information irrespective of its sources." Id. at 399. In Rbinebart the Court makes the similar argument that restraining orders are unlike classic prior restraints because the former prohibit speech based on only one sourcediscovery information-and leave the parties free to speak about the same subject based on information "gained through means independent of the court's processes." The trouble with this argument is that judicial injunctions prohibiting speech based on a single source of information have been viewed traditionally as classic prior restraints. See New York Times v. United States, 403 U.S. 713, 714 (1971). 
There might, of course, be government interests implicit in the functioning of pretrial discovery that are sufficiently substantial to justify the discretionary suppression of speech. But they must be identified and analyzed, so that their implications can be carefully assessed. For these purposes the Court's casual reference to "the unique character of the discovery process" is clearly insufficient.

\section{THE FIRST AMENDMENT RIGHTS OF LITIGANTS}

One method of resolving the tension between First Amendment rights and government discretion is to deny or diminish the First Amendment rights. The Court in Rbinebart appeared to employ this method. Although the Court stated that "litigants do not 'surrender their First Amendment rights at the courthouse door,' "85 it also implied that these rights were of a somewhat diminished constitutional significance. ${ }^{86}$ Since restraining orders plainly forbid speech, the cogency of this conclusion is less than obvious.

The Court justified its conclusion on the ground that restraining orders apply only to speech about information provided to the litigants as a matter of "legislative grace": ${ }^{87}$

[I]t is important to recognize the extent of the impairment of First Amendment rights that a protective order, such as the one at issue here, may cause. As in all civil litigation, petitioners gained the information they wish to disseminate only by virtue of the trial court's discovery processes. As the rules authorizing discovery were adopted by the state legislature, the processes thereunder are a matter of legislative grace. A litigant has no First Amendment right of access to information made available

${ }^{85} 104$ S.Ct. at 2207 n. 18 . The Court candidly acknowledged that defendants' speech did not fall "within the classes of unprotected speech" such as "fighting words" or obscenity, and that "there certainly is a public interest in knowing more about" the plaintiffs, an interest that "may well include most-and possibly all-of what has been discovered as a result of the court's order." 104 S.Ct. at 2206-07. These acknowledgments must be understood as an implicit rejection of the approach of the Supreme Court of Washington, which had argued that there was only a minimal public interest in the conduct of "civil actions," and that defendants' First Amendment rights were somehow diminished because their speech did not involve "advocacy or abstract discussion," but "only the reporting of supposed facts elicited in discovery." 654 P.2d at 686-88.

B6 The Court was somewhat unclear on this point, but concluded its discussion of litigants' First Amendment interests with the observation that "judicial limitations on a party's ability to disseminate information discovered in advance of trial implicates the First Amendment rights of the restricted party to a far lesser extent than would restraints on dissemination of information in a different context." 104 S.Ct. at 2208.

${ }^{87} 104$ S.Ct. at 2207. 
to him only for purposes of trying his suit. ... Thus, continued court control over the discovered information does not raise the same spectre of government censorship that such control might suggest in other situations. See In re Halkin, 598 F.2d, at 206-07 (Wilkey, J., dissenting).

The Court's reasoning is open to several interpretations. The first, suggested by the Court's reference to Judge Wilkey's dissenting opinion in In re Halkin, is that litigants receiving discovery information have only a "limited" First Amendment right in its dissemination, since they receive it "already subject to the courts' exercise of [a] discretionary power" of restraint. ${ }^{88}$ As Judge Wilkey forthrightly acknowledged, however, this reasoning is "very analogous to the view taken by Mr. Justice Rehnquist in Arnett v. Kennedy with respect to one's property interest in a government job. Therein Mr. Justice Rehnquist concluded that 'the property interest which appellee had in his [nonprobationary federal] employment was itself conditioned by the procedural limitations which had accompanied the grant of that interest.' "89

The difficulty with this argument is that Rehnquist's position in Arnett was specifically rejected by six other Justices, ${ }^{90}$ including Justice Powell, who noted thai Rehnquist's reasoning failed to perceive that even if benefits are received as a matter of "legislative grace," constitutional rights are not. ${ }^{91}$ Later decisions of the Court have reiterated this rejection of Rehnquist's position, ${ }^{92}$ and it is

${ }^{88}$ In re Halkin, 598 F.2d at 206 (Wilkey, J., dissenting).

${ }^{89}$ Id. at 207.

${ }^{90}$ Arnett v. Kennedy, 416 U.S. 153, 166-67 (1974) (opinion of Powell, J., joined by Blackmun, J.); 177-78 (opinion of White, J.); 210-11 (opinion of Marshall, J., joined by Douglas and Brennan, JJ.).

91416 U.S. at 166-67 (Powell, J., concurring). But see Goss v. Lopez, 419 U.S. 565, 58687 (1975) (Powell, J., dissenting). For recent studies of the vagaries of the Court's approach to the "right-privilege" distinction, and to its first cousin, the doctrine of "unconstitutional conditions," see Kreimer, Allocation Sanctions: The Problem of Negative Rigbts in a Positive State, 132 U. PA. L. Rev. 1293 (1984); Smolla, The Reemergence of tbe Rigbt-Privilege Distinction in Constitutional Law: The Price of Protesting Too Much, 35 STAN. L. REV. 69 (1982); Easterbrook, Substance and Due Process, 1982 SUPREME Court Review 85; Terrell, "Property," "Due Process," and tbe Distinction between Definition and Tbeory in Legal Analysis, 70 GEo. L.J. 861 (1982); Westin, Incredible Dilemmas: Conditioning One Constitutional Rigbt on the Forfeiture of Another, 66 Iowa L. REv. 741 (1981); Easterbrook, Insider Trading, Secret Agents, Evidentiary Privileges, and the Production of Information, 1981 SuPRElIE COLRT REVIEW 309, 348.

92 See Logan v. Zimmerman Brush Co., 455 U.S. 422, 431-32 (1982); Vitek v. Jones, 445 U.S. 480,490 n.6 (1980). 
implausible that Justice Powell meant by his unelaborated reference to Judge Wilkey suddenly to revive Rehnquist's approach.

A second interpretation of the Court's reasoning is that the legislature can condition production of discovery information on the sacrifice of First Amendment interests in the dissemination of such information. ${ }^{93}$ So characterized, however, this interpretation would appear to conflict with the doctrine of unconstitutional conditions. In its most extreme formulation, the doctrine holds that First Amendment rights may not "be infringed by the denial of or placing of conditions upon a benefit or privilege." view of the doctrine is that it functions primarily to deny that conditions placed upon the receipt of government benefits are constitutional simply because the benefits are a matter of legislative grace. The work of constitutionally analyzing such conditions must proceed free of any such conclusive arguments. ${ }^{95}$ Even in this more restricted form, however, the doctrine is in tension with the Court's opinion, which attempts to make just such a conclusive argument.

The Court's position may nevertheless be defended on the grounds that the doctrine of unconstitutional conditions ought not to apply to speech about discovery information. The argument could be made that the doctrine should only be applied to cases in which government conditions the receipt of state benefits on the sacrifice of constitutional rights that individuals would otherwise be free to exercise. Since there is no right or ability to speak about discovery information before it is provided by the government, the

${ }^{93}$ This interpretation differs from the first in that it is not, like Justice Rehnquist's view in Arnett, predicated on the assumption that constitutional rights can be defined by legislative benefits. It is noteworthy, in this regard, that Justice Powell quoted without expressly approving the Washington Supreme Court's observation that participation in discovery con"stitutes a "waiver" of First Amendment rights. See 104 S.Ct. at 2205 n.9. That observation is untenable. See Curtis Publishing Co. v. Butts, 388 U.S. 130, 145 (1967); Johnson v. Zerbst, 304 U.S. 458, 464 (1938). See also Schlagenhauf v. Holder, 379 U.S. 104, 114 (1964) ("constitutional problems" resulting from any theory that constitutional rights are waived merely from exercising "right of access to the federal courts").

${ }^{24}$ Sherbert v. Verner, 374 U.S. 398, 404 (1963).

9s The Sberbert Court recognized that the benefits at issue were a matter of legislative grace, but nonetheless examined the conditions on their receipt to determine if they were supported by a "compelling state interest." 374 U.S. at 403, 406-09. There was thus no conclusive presumption of either constitutionality or nonconstitutionality. See generally Westin, note 91 supra, at 748-51; Linde, Justice Douglas on Freedom in the Welfare State: Constitutional Rigbts in the Public Sector, 40 WaSH. L. ReV. 10 (1965); Van Alstyne, Tbe Constitutional Rights of Public Employees: A Comment on the Inappropriate Uses of an Old Analogy, 16 U.C.L.A. L. REv. 751 (1969). 
doctrine should have no application. In Sherbert $v$. Verner, for example, a Seventh-Day Adventist who believed as an article of religious faith that Saturday labor was forbidden, was required to work on Saturday as a condition of receiving unemployment compensation benefits. ${ }^{96}$ The premise of the Court's decision was that in the absence of government action, the Adventist was free to exercise her religious beliefs by refraining from Saturday labor. Conditioning unemployment benefits on Saturday labor functioned to "compel" her to violate these beliefs. There does not seem to be a similar compulsion operating on litigants, who cannot exercise their right to speak about discovery information until the government has acted to provide it to them.

This approach does seem to capture something of the unique character of restraining orders. Underlying it are two distinct lines of thought that need to be separately addressed. The first is that placing conditions on the receipt of discovery information does not compel litigants to sacrifice a preexisting constitutional right, since litigants cannot speak about information they do not yet have. This argument is unsatisfactory because it would make the constitutional analysis of a restraining order turn on the arbitrary circumstance of whether the order was issued before or after the receipt of discovery information. In Halkin, for example, the restraining order was issued only after litigants had received discovery information and had given written notice that they intended to release it to the press. ${ }^{97}$ Therefore the restraining order did in fact deprive litigants of a constitutional right to speak that they otherwise could have exercised. ${ }^{98}$ Similarly, the restraining order in Rbinebart was issued after some discovery information had already been produced. ${ }^{99}$ To apply a different constitutional analysis to this information would be bizarre, and it certainly does not appear to have been the Court's intention. Indeed, by strongly indicating its disapproval of Halkin, the Court signaled that its analysis could not be predicated upon

96374 U.S. at $399-401$.

97598 F.2d at $180-81$.

${ }^{98}$ It is thus doubtful that Judge Wilkey, in his Halkin dissent, meant to rest his argument on the absence of any preexisting constitutional right. Wilkey emphasized that it made no difference to his analysis of the de minimis nature of litigants' First Amendment rights whether a restraining order was issued "before or after the litigant's receipt of information." Id. at 207.

99 See note 43 supra. 
whether a restraining order was issued before or after the production of discovery information.

The Court's point, therefore, must be interpreted more broadly to mean that conditioning discovery on the sacrifice of First Amendment rights is permissible whenever the provision of the information makes possible the very exercise of these rights. The argument for this position is that the "spectre of government censorship" is reduced in such circumstances because the government retains the option to withhold the information that makes the rights exist at all.

This argument is both inconsistent with precedent and practically unsound. Indeed, little more than a month after Rhinebart the Court decided FCC v. League of Women Voters, ${ }^{100}$ which held that government contributions to noncommercial educational stations could not be conditioned upon a prohibition of the stations' editorial speech, even if such speech were made possible by the contributions. League of Women Voters is simply the latest in a line of decisions rejecting the contention that First Amendment rights made possible by government action can be prohibited by the government. Although the federal government created the United States mail as a matter of legislative grace, for example, it may not condition access to the mails upon the sacrifice of those First Amendment rights made possible by the use of the mail. The Court has held that "grave constitutional questions are immediately raised once it is said that the use of the mails is a privilege which may be extended or withheld on any grounds whatsoever." 101 Similarly, even if a local government builds a municipal auditorium that makes possible the exercise of First Amendment rights associated with theatrical productions, the availability of the auditorium must be "bounded by precise and clear standards," since, "the danger of censorship and of abridgment of our precious First Amendment freedoms is too great where officials have unbridled discretion over a forum's use."102

Viewed from this perspective, it is false to say, as the Court

${ }^{100} 104$ S.Ct. 3106 (1984).

${ }^{101}$ Hannegan v. Esquire, Inc., 327 U.S. 146, 156 (1946).

102 Southeastern Promotions v. Conrad, 420 U.S. 546, 553, 556 (1975). See also Madison School District v. Wisconsin Employment Rel. Comm'n, 429 U.S. 167, 176 (1976); Healy v. James, 408 U.S. 169, 181-83 (1972). 
implies, that the "spectre of government censorship" is less when government action makes possible the exercise of First Amendment rights. It does not take much imagination, for example, to envision the government's making the mail service selectively available to presidential candidates on the basis of their political views, or judges' imposing restraining orders on the basis of litigants' political affiliations. It is not, therefore, that the specter of censorship is reduced; it is rather that the Court believed the risk of censorship to be justifiable in the context of civil discovery. But at bottom this is a belief about the process of discovery, rather than about the nature of litigants' First Amendment rights.

The Court might have believed that the concept of a "diminished" First Amendment right would function both to permit the exercise of official discretion and to prohibit flagrant abuse such as overt political discrimination. But this use of the concept appears arbitrary and unsupported, since it is not clear why the concept would function in this manner. The Court made no effort to derive this function from traditional theories of freedom of expression, and it is unlikely that any such effort would have proved successful. The Court has repeatedly stressed that "the operations of the courts and the judicial conduct of judges are matters of utmost public concern," 103 and reference to discovery information can often be necessary to litigants' public evaluation of the judicial management of a case. Whether one examines such speech from the perspective of the "marketplace of ideas,"104 or of the information flow necessary for democratic self-governance, ${ }^{105}$ or of the "self-fulfillment" of the speaker, ${ }^{106}$ or of the "autonomy" of the listener ${ }^{107}$ there does not appear to be any reason to conclude that litigants' rights in the dissemination of discovery information are in any respect diminished.

In prior cases, moreover, the Court has properly and carefully distinguished between a right of access to information and a right to

\footnotetext{
${ }^{103}$ Landmark Communications v. Virginia, 435 U.S. 829, 839 (1978). See note 85 supra.

${ }^{104}$ See, e.g., Schauer, Free Speech: A Philosophical Enquiry 15-34 (1982); Abrams

v. United States, 250 U.S. 616, 630 (1919) (Holmes, J., dissenting).

${ }^{105}$ See, e.g., Meiklejohn, POlitical Freedon: The CONSTItLtional Poners of The PEOPLE (1948); De Jonge v. Oregon, 299 U.S. 353, 364-65 (1937).

106 See, e.g., EMerson, The Systeir of Freedom of EXPRession 6 (1970).

107 See, e.g., Scanlon, A Theory of Freedom of Expression, 1 PHIL. \& PUB. AFF. 204 (1972).
} 
disseminate such information once access has been obtained. Thus even in situations where government may legitimately bar access to information, the Court has found that First Amendment rights of dissemination can continue undiminished. ${ }^{108}$ In particular circumstances, of course, such rights may be subordinated to appropriate government interests in regulation. But in these circumstances it is more productive to focus on the nature of the asserted government interests, rather than on an undefined and intuitive diminution of First Amendment rights. Government interests in regulation are public and can provide the basis for constitutional dialogue. Thus, for example, if the Court were to have asserted that specific characteristics of the discovery process justify the need for trial court discretion to suppress speech, such an assertion could be made the subject of salutory and rational discussion. But discussion is ended by the deus ex machina appearance of a "diminished" First Amendment right that is unrelated to First Amendment theory or precedent, and that has content and contours that are neither described nor explained.

\section{The MANAgEMENT OF SPEECH AND THE ADMINISTRATION OF DISCOVERY}

The Court in Rbinebart was determined to reach a result that would insulate discretionary control over pretrial discovery from First Amendment challenge. The Court's difficulty in justifying this result can be explained in part by its reliance on traditional doctrinal formulations that embody values peripheral to the interests the Court was actually trying to protect. The Court never articulated these interests, but it provided us a clue to their nature by its reference to Procunier as the appropriate framework for First Amendment analysis. At first blush this reference seems peculiar: the First Amendment rights of prisoners do not seem an obvious standard for those of litigants. But the justification for the reference is made somewhat clearer by the subsequent citation of Brown $v$. Glines, ${ }^{109}$ in which the Court discussed the discretionary suppres-

${ }^{108}$ See, e.g., Landmark Communications, Inc. v. Virginia, 435 U.S. 829 (1978); New York Times v. United States, 403 U.S. 713 (1971).

${ }^{109} 444$ U.S. 348 (1980). 
sion of First Amendment rights in the military. ${ }^{110}$ What Procunier and Brown have in common is that both address the relationship between First Amendment rights and the internal management of a government institution.

The citation of these cases implies that underlying the Court's decision is the notion that pretrial discovery is a regime of judicial administration, rather than adjudication. From this perspective, the rules of civil procedure do not give litigants "rights" to information that must be adjudicated before a neutral and umpireal judge, but rather create a system of information exchange to be actively managed by a judge so as to secure "the just, speedy, and inexpensive determination of every action." 11 This perspective, of course, was explicitly adopted by the drafters of the 1983 amendments to the Federal Rules, which "encourage forceful judicial management" of "the entire pretrial phase, especially motions and discovery." 112 In his role as manager, the trial judge must consult not merely the interests of the particular parties before him, but the needs of the entire institution of pretrial discovery. He must make decisions based upon their effects on "other parties to other lawsuits."113

Administration of the system of pretrial discovery requires the continual exercise of judgment: judgment about whether "a party's aim is to delay bringing a case to trial, or embarrass or harass the person from whom he seeks discovery"; ${ }^{114}$ judgment about how to

110 The citations to Procunier and to Glines are followed by a reference to "Buckley v. Valeo, 424 U.S. I, 25 (1976)." 104 S.Ct. at 2207. This reference seems to be a mistake. The Court in Buckley explicitly refused to employ the test of United States v. O'Brien, upon which the formulations in both Procunier and Glines are based. The language in Buckley cited by the Rbinebart Court is instead an effort to apply the "closest scrutiny," which is not the Court's intention in Rbinebart, and which was not its purpose in either Procunier or Glines.

111 Wash. Super. Ct. C.R. I; Fed. R. Civ. P. 1. For a discussion of the emerging contrast between the managerial and umpireal images of the judge, see Resnik, Managerial Judges, 96 HaRv. L. Rev. 374 (1982); Kritzer, Tbe Judge's Role in Pretrial Case Processing: Assewing the Need for Change, 66 Judicature 28, 30 (June-July 1982).

112 Advisory Committee Notes to Rule 16, 97 F.R.D. 207, 213 (1983). Justice Powell has stressed the "pressing need for judicial supervision" of discovery to prevent abuse. ACF Industries, Inc. v. EEOC, 439 U.S. 1081, 1087 (1979) (Powell, J., dissenting from denial of certiorari).

${ }^{113}$ National Hockey League v. Metropolitan Hockey Club, Inc., 427 U.S. 639, 643 (1976). See Advisory Committee Notes to Rule 26, 97 F.R.D. 220 (1983). To adopt the language of the sociologist Philip Selznik, one might say that the judge's objective in administering pretrial discovery is "to achieve a desired outcome" rather than to attain "justice" between the parties. SELZNICK, LAW, SOCIETY, AND INDUSTRIAL JUSTICE 16 (1969).

${ }^{114}$ Oppenheimer Fund, Inc. v. Sanders, 437 U.S. 340, 353 n.17 (1978). 
instill "in counsel a sense of responsibility that will serve as a policing agent against harassment and oppression"; ${ }^{115}$ judgment about when discovery has become financially oppressive; ${ }^{116}$ judgment about when to teach counsel a lesson. ${ }^{117}$ No set of rules could comprehend the exercise of such judgment, ${ }^{118}$ and for that reason "flexibility and experience are the keys to efficient management" of pretrial discovery. ${ }^{119}$ Need for this flexibility has traditionally been recognized in the expansive authority and broad discretionary control to supervise the discovery process given to trial judges by both the Federal and Washington rules. ${ }^{120}$ "A judge must have discretion," as one jurist put it in a different context, "because without it the business could not go on."121

${ }^{115}$ Pollack, note 24 supra, at 225.

${ }^{116}$ SCM Societa Commerciale S.P.A. v. Industrial and Commercial Research Corp., 72 F.R.D. 110,112 (N.D. Tex. 1976); Glaser, Pretrial DisCovery AND THE ADVERSARY SYSTEM 182-85 (1968); Amendments to the Federal Rules of Civil Procedure, 85 F.R.D. 521, 523 (1980) (Powell, J., dissenting).

117 Note, Tbe Emerging Deterrence Orientation in the Imposition of Discovery Sanctions, 91 HaRV. L. REV. 1033, 1047 (1978).

${ }_{118}$ The trial judge is somewhat in the position of the police officers described by James $Q$. Wilson, for whom "no very useful-certainly no complete-set of instructions can be devised as to what the officer sbould do with, say, quarreling lovers. Defining a policy in such matters is difficult, not because the police have not given much thought to the matters or because they do not know how they should be handled, but because so much depends on the particular circumstances of time, place, event, and personality. Psychiatrists do not use how to do it' manuals, and they have the advantage of dealing with people at leisure, over protracted periods of time, and in periods of relative calm." WILSON, VARIETIES OF POLICE BEHAVIOR 65-66 (1968).

${ }^{119}$ Advisory Committee Notes to Rule 16, 97 F.R.D. 211 (1983).

${ }^{120}$ See text at notes $14-16 \&$ note 44 supra. The managerial perspective of pretrial discovery has been explicitly articulated primarily by those who have recently commented on the Federal Rules. The fact that this perspective has not been articulated in Washington law may have been one source of the Court's indirection in specifying the government interests at stake in Rule 26(c). But it is fair to say that from their promulgation in 1938, the Federal Rules of discovery implicitly envisioned the trial judge as a manager engaged in the "efficient administration" of justice, and to this end crcated a "judge-centered procedural model" which left trial judges "unfettered by rules" and able to meet "various situations . . . by wide exercise of judicial discretion." Fish, Guarding tbe Judicial Ramparts: Jobn J. Parker and the Administration of Federal Justice, 3 JusT. SYS. J. 105, 113 (1978). See Resnik, note 111 supra, at 391; Cutner, Discovery-Civil Litigation's Fading Ligbt: A Lawyer Looks at the Federal Discovery Rules after Forty Years of Use, 52 TEM. L. Q. 933, 936-37 (1979). Since Washington has essentially adopted all of the federal rules of discovery, with their philosophy of liberal information exchange and discretionary judicial control, it might also be said to have adopted the managerial perspective underlying these rules. At least, so the Court might have thought, Washington should constitutionally be free to adopt such a perspective if it should choose to do so.

${ }^{121}$ Reg. v. Winsor, 10 Cox C.C. 276, 321 (1866). See, e.g., Otero v. Buslee, 695 F.2d 1244, 1248 n. 1 (10th Cir. 1982). 
On this account, the crux of Rbinebart is neither the protection of privacy interests nor the diminishment of litigants' First Amendment interests, but rather the Court's perception that discretionary authority to issue restraining orders is essential for the administration of pretrial discovery. In this sense, the government's interests in restraining orders may be analogous to its interests in the management of other government institutions such as schools or prisons. These interests are quite different from those at stake when the government regulates the speech of the general public, as in the many cases where the Court has struck down discretionary authority to suppress speech.

The Court adverted to these management interests by its citation of precedents such as Procunier and Glines. Whether these precedents actually bear on the issues presented in Rbinebart, however, depends upon whether the government can be said to have generic interests in the regulation of state institutions, and whether these interests significantly affect applicable First Amendment standards.

\section{A. THE FIRST AMENDMENT AND THE MANAGEMENT OF GOVERNMENT INSTITUTIONS}

Although the Court has several times noted that "First Amendment guarantees must be 'applied in light of the special characteristics of the . . . environment," "122 the Court has not developed a systematic approach for the application of First Amendment standards to the management of government institutions. The Court has decided cases dealing with the assertion of First Amendment rights in the context of prisons, ${ }^{123}$ the military, ${ }^{124}$ government employment, ${ }^{125}$ and schools, ${ }^{126}$ but it has yet to provide any articulation of the structural similarities that unite these decisions.

122 Procunier v. Martinez, 416 U.S. 396, 410 (1974), quoting Tinker v. Des Moines School District, 313 U.S. 503, 506 (1969). See Healy v. James, 408 U.S. 169, 180 (1972).

${ }^{123}$ See Jones v. North Carolina Prisoners' Union, 433 U.S. 119 (1977); Pell v. Procunier, 417 U.S. 817 (1974); Procunier v. Martinez, 416 U.S. 396, 410 (1974).

${ }^{124}$ Brown v. Glines, 444 U.S. 348 (1980); Greer v. Spock, 424 U.S. 828 (1976); Parker v. Levy, 417 U.S. 733 (1974).

${ }^{125}$ Connick v. Myers, 103 S.Ct. 1684 (1983); Givhan v. Western Line Consolidated School District, 439 U.S. 410 (1979); Pickering v. Board of Education, 391 U.S. 563 (1968); cf. Snepp v. United States, 444 U.S. 507 (1980).

${ }^{126}$ Healy v. James, 408 U.S. 169 (1972); Tinker v. Des Moines School District, 313 U.S. 503 (1969). 
These similarities derive from the nature of government institutions, which are organizations "formally established for the explicit purpose of achieving certain goals." 127 The goal of the military is the national defense; the goal of the school system is education. Government institutions, like most formal organizations, have explicit authority structures that are integral to their capacity to attain institutional goals. ${ }^{128}$ Authority in government institutions typically extends to the speech as well as to the conduct of those subject to the management of the organization. For this reason speech that is insubordinate, that is expressed by those within an organization in defiance of its authority structure, threatens the ability of the institution to function.

The government's interests in the effective management of an institution are essentially its interests in the attainment of the institution's goals. The government therefore has rather strong interests in the regulation of insubordinate speech. These interests have three characteristics pertinent to the present inquiry. First, as the management of speech becomes more detailed and comprehensive, it makes little sense to distinguish between "prior restraints" and "subsequent punishments." Government organizations, for example, often require subordinates to clear with their superiors work-related memoranda before distribution. Constitutional analysis of such requirements should not turn on whether they can be characterized as imposing "prior restraints."

Second, within government institutions the distinction between permissible and impermissible speech routinely and necessarily turns on content. School boards, for example, characteristically instruct teachers that they are to use one curriculum rather than another; superiors characteristically instruct subordinates that they are to support at staff meetings one position rather than another;

${ }^{127}$ BLAU \& SCOTT, ForMal ORganIZations 5 (1962). On the ambiguities of the concept of a "goal," see SCOTT, ORGanizaTIONS: RATIONAL, NATURAL AND OPEN SYSTEMS 26164 (1981). In this article I will refer to an institution's "public" rather than "actual" goals. Public goals legitimate the institution in the eyes of the general society. ETziONi, A ComPARATIVE ANALYSIS OF COMPLEX ORGanizations 72 n.1 (1961). I do not mean to use the term "goal" to refer in any sense to the process of an organization's internal legitimation, or to imply that government organizations have become "infused with value" and hence have undergone what Selznick has described as a transition from organization to institution. SELZRICK, LEIDERSHIP IN ADMINISTRATION: A SOCIOLOGICAL INTERPRETATION 40, $134-$ 42 (1957). See Perrow, Complex Organizations: A Critical Essay 186-89 (1979).

${ }^{128}$ See, e.g., SimoN, ADMINisTrative Behavior 134-35 (1958); MARCh \& SiMON, ORganizations 194 (1958); BARNARD, THE FunCTiONS OF THE EXECUTIVE 159-84 (1968). 
generals characteristically instruct colonels that they are to formulate one kind of defensive plan rather than another. The management of speech within government institutions is thus an exception to the Court's often stated principle that "the First Amendment means that government has no power to restrict expression because of its message, its ideas, its subject, or its content."129

Third, government interests in the management of speech extend not merely to avoidance of damage caused by the particular speech regulated, but also to the integrity of the authority structure by which the speech is regulated. If insubordinate speech is constitutionally protected, the government will suffer not only the impact of the speech itself, but also a corresponding impairment of its authority, which may well have implications for its ability to manage other kinds of speech and conduct.

Although the government has a strong interest in the regulation of insubordinate speech, there may nevertheless be good reasons to extend constitutional protection to such speech. First Amendment values of individual "self-realization" 130 do not disappear simply because individuals choose to speak within the context of a government organization. Insubordinate speech may also provide a source of information that is important for the democratic supervision of government institutions. Although there is thus a tension between government interests and First Amendment values, the tenor of the Court's decisions in this area is that government institutions may discipline insubordinate speech that interferes with the accomplishment of institutional purposes. ${ }^{131}$ The Court's remarks in Tinker $v$. Des Moines School District are illustrative: "[C]onduct by the student, in class or out of it, which for any reason-whether it stems from

${ }^{129}$ Police Department of Chicago v. Mosley, 408 U.S. 92, 95 (1972). See, e.g., Consolidated Edison Co. v. Public Service Comm'n, 447 U.S. 530, 537-41 (1980).

${ }^{130}$ See, e.g., Baker, Commercial Speecb: A Problem in tbe Theory of Freedom, 62 lowa L. REv. $1,5-9$ (1976).

${ }^{131}$ See, e.g., Brown v. Glines, 444 U.S. 348, 356-57 (1980); Parker v. Levy, 417 U.S. 733, 758 (1974); Pell v. Procunier, 417 U.S. 817, 822 (1974); Jones v. North Carolina Prisoners' Union, 433 U.S. 119, 129-33 (1977); Healy v. James, 408 U.S. 169, 189 (1972). In its most recent discussion of the power of the government to regulate the speech of its employees, the Court stated that the Constitution "requires full consideration of the government's interest in the effective and efficient fulfillment of its responsibilities to the public." Connick v. Myers, 103 S.Ct. 1684, 1692 (1983). The Court also added a threshold test, to the effect that if employee expression "cannot be fairly characterized as constituting speech on a matter of public concern," government sanctions for the expression would not be subject to constitutional review. $1 d$. at $1689-90$. 
time, place, or type of behavior-materially disrupts classwork or involves substantial disorder or invasion of the rights of others, is, of course, not immunized by the constitutional guarantee of freedom of speech." 132

Although the Court is unlikely to immunize insubordinate speech that impairs the ability of a government institution to function, it will undertake its own independent inquiry into whether an institution's regulation of speech is necessary for attainment of organizational goals. This inquiry characteristically examines the authority structure of the relevant institution to determine the effect of constitutionally restricting its capacity to define and discipline the kind of insubordinate speech at issue. If the Court determines that the institution's legitimate authority structure will not be unduly damaged, it will then proceed to assess the impact of the particular speech at issue. These two aspects of constitutional inquiry are nicely illustrated in the contrast between Brown v. Glines and Tinker v. Des Moines School District.

In Glines, the Court upheld a military regulation prohibiting Air Force members from circulating petitions on military bases without prior approval of their commander. ${ }^{133}$ The regulation permitted base commanders to censor any petition they felt would create "a clear danger to the loyalty, discipline, or morale" of their troops. ${ }^{134}$ The Court did not consider it to be important that the regulation was a prior restraint and that it allowed censorship on the basis of the content of speech. The Court also did not ask whether the specific speech at issue would in fact have created a danger to loyalty, discipline or morale. Instead the Court rested its conclusion on the importance to the institution of the military to maintain "a respect for duty and a discipline without counterpart in civilian life": ${ }^{135}$ "The rights of military men must yield somewhat 'to meet certain overriding demands of discipline and duty. . . .' Speech likely to interfere with these vital prerequisites for military effectiveness therefore can be excluded from a military base." In the Court's view "the military mission" required creation of a form of

\footnotetext{
132393 U.S. 503, 513 (1969).

133444 U.S. at 349.

${ }^{134}$ Id. at 350 .

I3s Id. at 354 .
} 
authority founded on "instinctive obedience."136 The overriding constitutional concern was the maintenance of this kind of authority, ${ }^{137}$ regardless of the effects of the particular speech at issue.

In Tinker v. Des Moines Scbool District, on the other hand, the Court was unwilling to place a constitutional imprimatur on this kind of authority. In Tinker the Court struck down a school regulation prohibiting the wearing of black armbands to protest the Vietnam war. The Court rested its conclusion on the premise that "[i]n our system, state-operated schools may not be enclaves of totalitarianism. School officials do not possess absolute authority over their students." ${ }^{138}$ Hence school officials, unlike military commanders, could not prohibit expression on the basis of an "undifferentiated fear or apprehension of disturbance," but could only act on the basis of "facts which might reasonably have led [them] to forecast substantial disruption of or material interference with school activities." ${ }^{139}$ Since these facts were absent in Tinker, the Court found the regulation unconstitutional.

The difference between the First Amendment standard applied in Tinker and that applied in Glines rests on a form of constitutional sociology, on the Court's judgment about the structure of authority appropriate and necessary for different government institutions. In Tinker the Court believed that schools could continue to function even though they were prevented from regulating certain kinds of speech in the absence of evidence sufficient to convince a reviewing court that censorship was necessary to avoid disruption. In Glines the Court believed that the need for unquestioned military authority was more important than the propriety of any particular exercise of that authority. In both Tinker and Glines, government officials were empowered to suppress speech that interfered with the effective functioning of their institutions, but the needs of military authority, unlike those of school officials, were deemed to require

\footnotetext{
${ }^{136}$ Id. at $354,357$.
}

137 The Court indicated that such authority was not unlimited, stating that "commanders may sometimes apply these regulations 'irrationally, invidiously, or arbitrarily,' thus giving rise to legitimate claims under the First Amendment." Id. at 357 n.15. The qualification should be understood as the Court's reservation of ultimate authority to determine whether the purpose of military censorship is the achievement of institutionally legitimate ends.

138393 U.S. at 511.

${ }^{139} \mathrm{Id}$. at 508 . 
that the military retain "substantial discretion over its internal discipline" in the regulation of insubordinate speech. ${ }^{140}$

When it comes to the regulation of insubordinate speech, therefore, the ordinary relationship between the First Amendment and discretion is inverted. If government officials act to regulate the speech of the general public, the First Amendment usually imposes strict limitations on the administrative discretion that can be delegated to such officials. But when these same officials act to manage speech within the context of a government institution, the administrative discretion constitutionally deemed necessary for effective management determines the First Amendment standard to be applied. ${ }^{141}$

\section{B. RESTRAINING ORDERS AND THE MANAGEMENT OF PRETRIAL DISCOVERY}

The relationship between the First Amendment and discretion is thus significantly affected by the context of the government regulation at issue. If the regulation occurs in the context of the internal management of a state institution, the First Amendment will permit such discretion as is necessary for the effective management of the institution. The question, therefore, is whether restraining orders should constitutionally be viewed as involving the internal management of the court system.

We ordinarily think of trial courts as adjudicative institutions which govern litigants by law rather than by "managerial direc-

\footnotetext{
140444 U.S. at 357.
}

${ }^{141}$ In Snepp v. United States, 444 U.S. 507 (1980), the Court endorsed the use of a contract, "voluntarily signed" without "duress," as a basis for regulating the speech of a former CIA employee. Id. at 509 n.3. Snepp, however, provides a poor basis from which to generalize about government regulation of insubordinate speech. This is because the decision ultimately rests on the concept of "consent." But consent is not present in various management situations, as, for example, those in schools, prisons, or the military. See note 93 supra. Moreover the line between voluntary and involuntary consent is difficult to draw in management situations. For example, when government requires as a condition of eniployment that employees sign explicit contracts forgoing First Amendment rights, serious questions can and should arise concerning the validity of such "consent." See, e.g., National Security Decision Directive 84, Hearing Before the Committee on Governmental Affairs of the United States Senate, 98th Cong., 1st Sess. 85 (September 13, 1984); Powe, Tbe Constitutional Implications of President Reagan's Censonbip Directive 84, THE CENTER MAGAZINE 8 (March/April 1984). The issue, therefore, is more directly addressed by asking whether government has the power to regulate insubordinate speech, rather than whether it can wring "consent" to such regulation from its employees. 
tion." ${ }^{142}$ But the judicial system, like any other government institution, needs to accomplish its goals, which may for convenience be taken to be those specified in both the Federal and Washington rules: the securing of "the just, speedy, and inexpensive determination of every action." 143 To accomplish these ends, trial courts are traditionally vested with administrative authority. This can plainly be seen in a trial court's supervision of its courtroom. The trial judge has been accurately described as "the executive of the courtroom. Among his duties and powers are those of presiding, of preserving order and decorum, of regulating the conduct of those who participate in the proceedings, and of directing and guiding such proceedings . . . to the end that there may be such economy of time, effort, and expense as is commensurate with the rights of the parties to present their claims and defenses." 144

The trial judge's management of the courtroom extends to the regulation of speech. Even in Bridges v. California, when the Court, speaking through Justice Black, imposed strict limitations on a trial judge's capacity to punish by contempt the out-of-court speech of nonparties, the Court made a point of strongly reaffirming the constitutional power of trial judges "to protect themselves from disturbances and disorder in the court room by use of contempt proceedings." 145 Courtroom speech can be regulated on the basis of its content, as, for example, when courts permit argument on certain points rather than others, or punish by contempt remarks they

142 Fuller, THE MORALITY of LAw 210 (1969). Fuller views the "basic difference between law and managerial direction" to be that "law is not, like management, a matter of directing other persons how to accomplish tasks set by a superior, but is basically a matter of providing the citizenry with a sound and stable framework for their interactions with one another." Ibid.

${ }^{143}$ Fed. R. Civ. P. 1; Wash. C. R. 1.

${ }^{144}$ Bowers, The Judiclal Discretion of Trial Courts 10 (1931). See Smith v. Smith, 17 N.J. Super. 128, 85 A.2d 523 (1951); Amo v. Genovese, 17 N. J. Super. 109, 85 A.2d 529 (1951). Trial courts have traditionally been accorded "discretion" in the exercise of these administrative responsibilities. See Bowers, at 267-492; McKean, Some Aspects of Judicial Discretion, 40 DICK. L. REV. 168, 170-71 (1936).

${ }^{145}$ Bridges v. California, 314 U.S. 252, 266 (1941). In Wood v. Georgia, 370 U.S. 375, 383 (1962), a case concerned with the trial court punishment of out-of-court speech, the Court states: "We start with the premise that the right of courts to conduct their business in an untrammeled way lies at the foundation of our system of government and that courts necessarily must possess the means of punishing for contempt when conduct tends directly to prevent the discharge of their functions . . [ [C]ourts have continuously had the authority and power to maintain order in their courtrooms and to assure litigants a fair trial . .." 
consider insulting. ${ }^{146}$ And courtroom speech is commonly regulated in ways that in other contexts would constitute prior restraints, as, for example, when a judge reviews evidence to decide whether it can be given to the jury. Such regulation is not thought to raise particular First Amendment problems, and this is what one would expect if the regulation were an issue of internal managerial authority.

The premise of the movement toward "case management"147 is that this same kind of managerial authority should extend to the pretrial process. This is consistent with the original desigu of the Federal Rules of Civil Procedure, which "vindicated a particular version of judicial administration that sharply modified the preexisting adversary control over all aspects of litigation" and "established on a secure footing the power of the judge as the manager of the case. ${ }^{148}$ In complex cases this pretrial managerial power has long been self-consciously exercised. The epigraph to the Manual for Complex Litigation, for example, states: "There are no inherently protracted cases, only cases which are unnecessarily protracted by inefficient procedures and management."149 And in 1983 the pretrial managerial authority of the trial judge was strongly emphasized in the amendments to the federal rules, which explicitly encourage "forceful judicial management" of "the entire pretrial phase, especially motions and discovery."150

$1+6$ "Courts of justice are universally acknowledged to be vested ... with power to impose silence, respect and decorum in their presence, ... and as a corollary to this proposition, to preserve themselves and their officers from the approach and insults of pollution." Anderson v. Dunn, 19 U.S. (6 Wheat.) 204, 227 (1821). See Consolidated Edison Co. v. Public Serv. Comm'n, 447 U.S. 530, 544-46 (1980) (Stevens, J., concurring); Dobbs, Contempt of Court: A Survey, 56 CORNELl L. Rev. 185, 186-207 (1971).

147 Flanders, Case Management and Court Management in United States DisTRICT COURTS (1977). For a good survey of the literature on case management, see Resnik, note 111 supra.

${ }^{148}$ Horowitz, Decreeing Organizational Cbange: Judicial Supervision of Public Institutions, 1983 Duke L.J. 1265, 1271. See ConNolly, Holleman, \& Kuhlian, Judicial Controls AND THE Civil LiTigation PROCESS: DisCOVERY 14 (1978). Since Washington has adopted the federal rules, it might also be viewed as having adopted the managerial perspective underlying these rules. See note 120 supra.

149 Manual for Complex Litigation, at $\mathrm{v}$.

15097 F.R.D. 207, 213. "[C]lose supervision of discovery" has been termed "the most widespread and urgent policy concern today about the way that the litigation system functions." Flanders, Blind Umpires-a Response to Professor Resnik, 35 HAST. L.J. 505, 514-15 \& n.49 (1984). 
When a trial court exercises managerial control of the courtroom, however, there is little chance for confusion about whether an individual is within its administrative authority. In this respect a trial judge's courtroom governance is like that of a school administrator: it is generally clear enough whether a student is or is not subject to school regulation. But managerial and nonmanagerial authority cannot be so clearly distinguished during the pretrial phase of litigation. If a school were to promulgate a dress code that forbade the wearing of jeans while at home, we would say that the code was not an exercise of managerial authority, since it had nothing to do with the running of the school. ${ }^{151}$ But a trial judge can issue a restraining order that prohibits litigants from speaking even though they are not in the actual or constructive presence of the court. The question is whether such an order is an exercise of managerial authority.

The question is illuminated by the Court's decisions in the area of government employment. Government agencies sometimes attempt to extend their managerial authority to employee speech that occurs out of the office. In Pickering $v$. Board of Education, ${ }^{152}$ for example, a teacher had been dismissed for sending a letter to a newspaper that was critical of the school board. Since the teacher's speech neither "impeded [his] proper performance of his daily duties in the classroom" nor "interfered with the regular operation of the schools generally," the Court concluded that "the interests of the school administration" in controlling the speech were "not significantly greater than its interest in limiting a similar contribution by any member of the general public." 153 The government, in other words, could not invoke its interests as a manager to justify regulation of the speech, even though the speech may have adversely affected the school administration's ability to achieve institutional goals. ${ }^{154}$

${ }^{151}$ See, e.g., Thomas v. Bd. of Educ., 607 F.2d 1043 (2d Cir. 1979), cert. denied, 444 U.S. $1081(1980)$.

152391 U.S. 563 (1968).

${ }^{153} \mathrm{Id}$. at $572-73$.

${ }^{154}$ In a recent line of cases, the Court has used the "public forum" doctrine to develop First Amendment standards concerning the capacity of government institutions to regulate members of the general public seeking to use the instrumentalities of the institution to assist them in their speech. See Perry Education Ass'n v. Perry Local Educators' Ass'n, 103 S.Ct. 948 (1983); Greer v. Spock, 424 U.S. 828 (1976). 
When a trial court issues a gag order prohibiting the press from writing about a pending criminal trial, the court is in a similar position to the school board in Pickering. It is attempting to regulate speech that will adversely affect the operation of the judicial system, but over which it has no specifically managerial interests. The court's regulation of the press must therefore be viewed as an attempt to govern the general public.

The situation is different, however, when a trial court issues a restraining order prohibiting a litigant from speaking about discovery information obtained through the court's own processes. The court is directly engaged in the supervision of the pretrial activities of the litigant, and its decisions in the course of that supervision will directly depend on whether the litigant can speak about discovery information. In cases involving commercially sensitive information, for example, a court may be willing to order discovery only if it can be assured that the information will remain confidential. If a court is uncertain whether pertinent information is being sought for proper or improper purposes, it may choose to order production of the information only if it can ensure that the information will be properly used. In such situations restraining orders are necessary to achieve the pretrial exchange of information thought prerequisite for the effective functioning of the judicial system.

To view restraining orders as an exercise of managerial authority is essentially to see them as ancillary to a trial court's task of declaring the law between the parties. They are a tool used by the trial court to control the behavior of parties so as to create the conditions of achieving a just resolution of their dispute. ${ }^{155}$ The First Amendment will permit employment of this tool if it is necessary to attain the legitimate objectives of the judicial system. ${ }^{156}$ And, more im-

155 This is the manner in which the Court viewed the old "bill of discovery" that was superseded by the modern federal rules. The bill was seen as "an auxiliary process in aid of trial at law" whose function was "to give facility to proof." Sinclair Refining Co. v. Jenkins Petroleum Process Co., 289 U.S. 685, 693 (1933).

${ }^{156}$ The Court has clearly indicated that the First Amendment will not protect insubordinate speech that interferes with the ability of the judicial system to attain its institutional ends. See note 145 supra. In 1966 the Court, speaking in the context of prejudicial pretrial publicity, concluded that a trial court could prohibit the out-of-court speech of "prosecutors, counsel for defense, the accused, witnesses, court staff [and] enforcement officers coming under the jurisdiction of the court" if such speech would "frustrate its function." Sheppard v. Maxwell, 384 U.S. 333, 363 (1966). See Gulf Oil Co. v. Bernard, 452 U.S. 89, 104 n.21 (1981). 
portant, the First Amendment will also cede to trial judges discretion to determine if a particular restraining order is necessary to attain such legitimate objectives, but only if it can also be demonstrated that such discretion is essential for effective management of pretrial discovery.

The constitutionality of the "broad discretion" authorized by Rule 26(c) will thus depend upon an inquiry into the nature and extent of the discretion necessary to control pretrial discovery. But the Court's implicit premise that law and discretion are incompatible makes such an inquiry impossible, for it implies that all legal restraint on judicial discretion is unacceptable. The premise renders trial court discretion constitutional by definition. It is thus inconsistent with sensitive constitutional analysis, and with any serious investigation into the means whereby rights and discretion may be accommodated. The premise is, moreover, factually false.

\section{Three Perspectives on Discretion}

Without doubt the prevailing conception of discretion is that it "signifies choice." 157 Maurice Rosenberg, for example, has written that "if the word discretion conveys to legal minds any solid core of meaning, one central idea above all the others, it is the idea of choice." 158 And Kenneth Davis has defined an official as having discretion if "the effective limits on his power leave him free to make a choice among possible courses of action or inaction." 159

This view of discretion prevails in Supreme Court opinions. Whenever the Court speaks, as it often does, of the "deference

${ }^{157}$ Johnson v. United States, 398 A.2d 354, 361 (D.C. App. 1979). See Smith v. Smith, 17 N.J. Super. 128, 85 A.2d 523, 524 (N.J. App. 1951) (" '[J]udicial discretion' is the option which a judge may exercise between the doing and the not doing of a thing which cannot be demanded as an absolute legal right. ..."); Wendel v. Swanberg, 384 Mich. 468, 185 N.W.2d 348,351 (1971) ("The term discretion itself involves the idea of choice . . .").

${ }^{158}$ Rosenberg, Judicial Discretion of the Trial Court, Viewed from Above, 22 SYRAClSE L. Rev. 635, 636 (1971). See Dworkin, Judicial Discretion, 60 J. PHIL. 624, 625 (1963); Vorenberg, Decent Restraint of Prosecutorial Power, 94 HARv. L. Rev. 1521, 1523-24 (1981).

${ }^{159}$ Davis, note 2 supra, at 4 . See DeSMith, Judiclal Review of Adilnistrative ACTION 278 (4th ed. 1980) ("The legal concept of discretion implies power to make a choice between alternative courses of action"); JAFFE, JUDICIAL CONTROL OF ADMINISTRATIVE ACTION 359 (1965) ("We may . . . define discretion as a power to make a choice within a class of actions"); HART \& SACHS, THE LEGAL PROCESS 162 (1958) (unpublished manuscript) ("discretion means the power to choose between two or more courses of action each of which is thought of as permissible"); Wexler, Discretion: The Unacknowledged Side of the Law, 25 TORONTO L.J. 120, 123 n.8 (1975). 
federal courts should pay to the informed discretion" of public officials, ${ }^{160}$ it has in mind the notion that officials have a certain freedom of choice that must be respected. This same freedom of choice is undoubtedly what the Court meant to preserve with its concept of "discretion" in Rbinebart.

The difficulty with viewing discretion in this manner is that it reinforces the notion that law and discretion are mutually exclusive. Law, after all, "imposes an environment of constraint, of tests to be met, standards to be observed, ideals to be fulfilled." 161 And if discretion is viewed as choice, it is all too easy to begin to think of it as that "residue" of pure free choice which remains after all forms of legal control are eliminated. ${ }^{162}$ This way of thinking can lead directly to the image of discretion as "the hole in the doughnut, . . . an area left open by a surrounding belt of restriction." 163 The area of discretion expands or contracts, as surrounding legal restrictions grow or diminish; but by definition discretion (choice) and law (restraint) cannot occupy the same space at the same time. It is this image that appears to underlie the Court's opinion in Rbinebart.

It is a misleading image, however, for it focuses attention on the presence or absence of discretion, rather than on the intricate ways in which discretion and law interact in the process of decision making. It invites us to conceptualize choice as a single, unitary act that is either free or constrained, rather than as a complex process. Our judicial system contains numerous examples of decision making that is both discretionary and guided by legal standards. But since we have no disciplined method to bring these examples easily to mind, we do not use them in analysis of unfamiliar circumstances, such as Rbinebart.

These examples suggest that trial court discretion to manage pretrial discovery can be analyzed in at least three distinct dimensions. Trial courts can have discretion with respect to controlling

160 Jones v. North Carolina Prisoners' Union, 433 U.S. 119, 136 (1977). See, e.g., Block v. Rutherford, 104 S.Ct. 3227, 3235 (1984); Curtiss-Wright Corp. v. General Electric Co., 446 U.S. 1, 10 (1980); Bell v. Wolfish, 441 U.S. 520, 546 n.28 (1979); Hutto v. Finney, 437 U.S. 678,688 (1979).

${ }^{161}$ Selzivick, note 113 supra, at 11.

162 See Simon, Smithburg, \& Thompson, Public Administration 514 (1950); $c f$. Stewart, The Reformation of American Administrative Law, 88 HARV. L. REV. 1669, 1697 (1975).

${ }^{163}$ Dworkin, note 1 supra, at 31. 
legal standards, with respect to the reviewing power of appellate courts, and with respect to structural characteristics of their decision-making process, such as the obligation to articulate reasons for their decisions. Trial court discretion can exist in various degrees in each of these dimensions, and it can exist in some dimensions and not in others.

\section{A. DISCRETION AND APPLICABLE LEGAL STANDARDS}

The common law traditionally distinguished between "the incertain and crooked cord of discretion" and "the golden and straight mete-wand of the law." 164 Accustomed to view the law as a system of general rules imposing "restraint and regulation" on judicial decision, ${ }^{165}$ the common law distrusted judicial discretion, ${ }^{166}$ since a discretionary decision was one in which there were "no fixed principles by which its correctness may be determined."167 The classic statement, often repeated in nineteenth-century American cases, is by Lord Camden, who said that "[ $t]$ he discretion of a judge is the law of tyrants; it is always unknown; it is different in different men; it is casual and depends upon constitution, temper, and passion." ${ }^{168}$ American judges embroidered the theme. A justice of the Alabama Supreme Court, for example, inveighed against "the uncertainty of a power, so uncontrollable and liable to error as mere judicial discretion-a power that may possibly be misdirected by a fit of temporary sickness, an extra mint julep, or the smell of a peculiar overcoat."169

The primary means by which nineteenth-century American courts reconciled themselves to judicial discretion was to view it, in the manner of Chief Justice Marshall, as a term of art. "Courts are

${ }^{164}$ See Smith, note 69 supra, at 30; Conway v. The Queen, I Cox C.C. 210, 216 (1845).

${ }^{165}$ Pound, The Causes of Popular Dissatisfaction with the Administration of Justice, 35 F.R.D. 273, 275-76, 278 (1964) (originally published at 29 A.B.A. REP. (1906)).

166 Pound, Discretion, Dispensation and Mitigation: The Problem of the Individual Special Case, 35 N.Y.U. L. REv. 925, 926-28 (1960).

${ }^{167}$ Palliser v. Home Telephone, 170 Ala. 341, 54 S. 499, 500 (1911).

${ }^{168}$ Doe v. Kersey (1765) (C.P.) (Unreported), quoted in FEARNE, CONTINGENT REMiaiNDERS AND EXECUTORY DEvises $535 \mathrm{n}$.(t) (3d Am. ed. 1826). See State v. Cummings, $36 \mathrm{Mo}$. 263, 279 (1965), rev'd, 71 U.S. 277 (1866). Hence the proverb: "That system of law is best which confides as little as possible to the discretion of the judge; that judge is best who trusts as little as possible to himself." OSBORN, A CONCISE LAW DICTIONARY 198 (1927).

${ }^{169}$ Ex parte Chase, 43 Ala. 303, 311 (1869). 
the mere instruments of the law," he said, "and can will nothing." 170

When they are said to exercise a discretion, it is a mere legal discretion, a discretion to be exercised in discerning the course prescribed by law; and, when that is discerned, it is the duty of the court to follow it. Judicial power is never exercised for the purpose of giving effect to the will of the judge; always for the purpose of giving effect ... to the will of the law.

While this perception could be readily assimilated to a traditional view of law as a system of restraints, it also seemed to deny the very existence of judicial discretion. Frustration with this apparent paradox led one nineteenth-century jurist to exclaim that "when applied to public functionaries" the term discretion means ${ }^{171}$

a power or right conferred upon them by law, of acting officially in certain circumstances, according to the dictates of their own judgment and conscience, uncontrolled by the judgment or conscience of others. But what is to be understood by a discretion that is governed by fixed legal principles is, I must be allowed to say, something that I have not found satisfactorily explained, and what it is not easy for me to comprehend, Poetry may be indulged the license of saying,

We have a power in ourselves to do it, but it is

A power which we have no power to do.

The paradox that so troubled the jurist is to modern eyes easily resolved once it is understood that the attribution of discretion can be relative. From the viewpoint of an appellate court, for example, a trial judge may have discretion with respect to the determination of a defendant's sentence, since the judge can (within limits) choose the standards that will guide the sentencing process, and the appellate court will not interfere. ${ }^{172}$ With respect to the appellate court, the sentencing judge is not bound by enforceable legal rules, and can act according to the dictates of judgment and conscience.

From the viewpoint of the sentencing judge, however, there is nevertheless an official decision to be made according to legal crite-

${ }^{170}$ Osborn v. Bank of the United States, 22 U.S. (9 Wheat.) 326, 381 (1924). See, e.g., Langnes v. Green, 282 U.S. 531, 541 (1931); Lent v. Tillson, 140 U.S. 316, 329 (1891); Tingley v. Dolby, 13 Neb. 371, 14 N.W. 146, 147-48 (1882); Scott v. Marley, 124 Tenn. 388, 1317 S.W. 492, 493 (1911).

${ }^{171}$ Judges v. People, 18 Wend. 79, 99 (1837).

${ }^{172}$ United States v. Mejias, 552 F.2d 435, 447 (2d Cir.), cert. denied, 434 U.S. 847 (1977). 
ria. The sentencing judge does not perceive himself as free to act on purely personal motives or private desires. He cannot decide the proper sentence by flipping a coin. He might instead feel himself bound to choose the appropriate legal policies-whether they be deterrence, punishment, or rehabilitation-and to do his best to implement them. He can be, from his own perspective, an "instrument of the law."

It is rather common for trial court decisions to be governed by legal standards, even though the decisions are "discretionary" from the point of view of an appellate court. This is typical of the structure of the Federal Rules of Civil Procedure. Rule 26(b), for example, provides that the decision with respect to permissive intervention should lie within the "discretion" of the trial court, meaning that the decision "is not reviewable by an appellate court unless clear abuse is shown." "173 Yet the Rule also states explicit criteria to guide the trial judge's decision even in the absence of appellate review. ${ }^{174}$ From the point of view of the trial judge, then, the decision whether to permit intervention is governed by authoritative legal standards. This combination of discretion and constraint characterizes the Court's treatment of discretion in a variety of areas. The decision whether to dismiss an action for forum non conveniens, for example, "is committed to the sound discretion of the trial court" and "may be reversed only when there has been a clear abuse of discretion." 175 Yet the Court has promulgated a list of no less than twelve "factors" to be evaluated by the trial court in the exercise of its discretion. ${ }^{176}$

There can, of course, be situations in which a trial court is, from its own perspective, free from guiding legal standards. An example offered by an early writer is a judge's control of the court calendar. In the decision to fix "a day for appearance," the judge is not bound to act "according to his ideas of right," but rather may act "as he pleases." 177 In such circumstances, we might say, there is no law to

${ }^{173}$ Allen Calculators, Inc. v. National Cash Register Co., 322 U.S. 137, 142 (1944).

${ }^{174}$ Rule 24(b) states: "In exercising its discretion the court shall consider whether the intervention will unduly delay or prejudice the adjudication of the rights of the original parties."

${ }^{175}$ Piper Aircraft Co. v. Reyno, 454 U.S. 235, 257 (1981).

${ }^{176}$ Id. at 241 n.6.

177 Kaufman, Judicial Discrction, 17 AM. L. REV. 567, 567 (1883). 
guide the judge's decision. The question whether a decision is discretionary from the point of view of a trial court, therefore, depends upon the presence or absence of legal standards. It is fair to say, however, that such discretion is rare: as Justice Frankfurter once observed, "Discretion without a criterion for its exercise is authorization of arbitrariness." 178

The concept of point of view thus illustrates the distinction between trial court discretion resulting from the absence of appellate review, and trial court discretion resulting from the absence of applicable legal standards. The two forms of discretion are related in a complicated manner: A trial court decision can be bound by legal rules and yet be immune from appellate supervision. But a decision that is truly unguided by legal standards will necessarily be discretionary from the point of view of an appellate court. ${ }^{179}$

The Court in Rbinebart, because of its implicit assumption that discretion was simply the power to choose, overlooked the distinction between these forms of discretion. The Court clearly held that the First Amendment does not prohibit appellate courts from viewing the decision to issue a restraining order as discretionary. ${ }^{180}$ But the Court did not address the question whether such a decision is discretionary from the point of view of the trial court itself. Need the trial court consider constitutional standards when deciding whether to issue a restraining order, or are such standards irrelevant to its decision? The Supreme Court did not tell us. It did not even raise the issue.

The omission cannot be justified. Once the Court acknowledged that litigants retain some First Amendment interests in the dissemination of discovery information, it incurred a concomitant responsibility to articulate controlling constitutional principles for defining and protecting those interests. Since the requirements of the Constitution do not emanate solely from the commands of appellate courts, these principles would constrain trial court decisions even in the absence of appellate review.

It does not follow that such constitutional principles will necessarily convert trial courts into "instruments of the law" that are,

\footnotetext{
${ }^{178}$ Brown v. Allen, 344 U.S. 433, 496 (1953) (Opinion of Frankfurter, J.).

179 See Friendly, Indiscretion about Discretion, 31 EMORY L.J. 747, 765 (1982).

${ }^{180}$ The Court approved an "abuse of discretion" standard of appellate review. 104 S.Ct. at 2209.
} 
from their own perspective, without discretion. This is because the kind of trial court discretion that stems from applicable legal standards is a gradient which can exist in varying degrees. This can be seen if one imagines legal standards as arranged along a spectrum. ${ }^{181}$ At one end are standards that give no guidance to a decision maker. An example would be a statute authorizing a policeman to regulate traffic "as he thinks fit." 182 Such a statute would deprive the policeman of any law to apply and would create a situation in which his decisions were, from his own point of view, discretionary. At the other end of the spectrum are standards that function as specific rules, mechanically requiring a decision maker to reach one result or the other. An example would be a statute authorizing a policeman to regulate an intersection by requiring traffic to move for two minutes in one direction, and three minutes in the other. Such a statute would leave virtually no room for the exercise of discretion. A policeman following its instructions would properly view himself as a mere "instrument of the law."

The vast majority of legal standards will fall in the middle range of the spectrum, and will neither completely cede nor completely withhold discretion. These standards will have an open texture requiring the exercise of independent judgment for their implementation. An example would be a statute authorizing a policeman to regulate traffic "to avoid undue congestion." When the Court in Rbinebart concluded that Rule 26(c) gave trial courts room for the exercise of "broad discretion," it meant this sense of discretion informed by legal standards. Ronald Dworkin calls this " 'discretion' in a weak sense," and observes that it exists whenever "for some reason the standards an official must apply cannot be applied mechanically but demand the use of judgment." 183

"Weak" discretion exists in varying degrees. Different First Amendment standards will thus cede more or less weak discretion to trial courts in the issuance of restraining orders. A First Amendment standard could consist of specific and mechanical rules stating when restraining orders would constitutionally be deemed as neces-

${ }^{181}$ See Gifford, Discretionary Decisionmaking in the Regulatory Agencies: A Conceptual Framework, 57 S. CAL. L. REv. 101, 102 (1983).

182 These examples are suggested by Jowell, The Legal Control of Administrative Discretion, 1973 PCB. LAW 178, 179-80.

${ }^{183}$ Dworkin, note 1 supra, at 31. 
sary for effective management of pretrial discovery. Or a First Amendment standard could consist of a more general statement of constitutional objectives, such as that restraining orders should not unnecessarily interfere with litigants' First Amendment rights. An important factor in the selection of an appropriate First Amendment standard should be the extent of weak discretion necessary to assure effective management of pretrial discovery.

\section{B. DISCRETION AND APPELLATE CONTROL}

It is often difficult to distinguish trial court discretion arising from the absence of appellate control from the kind of weak discretion entailed by the open texture of a legal standard. Commentators sometimes assume that as weak discretion increases, the possibility of effective appellate control correspondingly diminishes. ${ }^{184}$ The assumption is inaccurate. The exercise of appellate control is independent of the specificity or generality of the law to be applied. Appellate courts can exercise strict control of trial court decision making even when applying general standards, and, conversely, there are situations (although rare) when appellate courts give only cursory review to judgments controlled by the most specific and mechanical of legal rules. ${ }^{185}$

Like weak discretion, trial court discretion arising from the absence of appellate review is a gradient that exists in varying degrees. The stricter the form of appellate review, the less discretion a trial court can be said to have. For our purposes, three forms of appellate control should be distinguished, which I shall call (1) independent review, (2) deference, and (3) delegation.

The "rule of independent review," which was strongly reaffirmed this Term, holds that it is the "constitutional responsibility" of an appellate court independently to examine the record in cases in which First Amendment rights are denied. ${ }^{186}$ Appellate courts applying the rule essentially view trial court determinations of First Amendment rights as questions of law, to be independently redecided by the appellate court after full scrutiny of the record. The

\footnotetext{
${ }^{184}$ See, e.g., Friendly, note 179 supra, at 760-61; Rosenberg, note 158 supra, at 663.

${ }^{185}$ For example, appellate courts commonly both accord the decisions of juries great deference and ask them to make those decisions pursuant to strict and rigorous rules of law. ${ }^{186}$ Bose Corp. v. Consumers Union, 104 S.Ct. 1949, 1959 (1984).
} 
underlying assumption is that application of appropriate First Amendment standards will yield a single correct legal conclusion, which the trial court either did or did not reach. This is true even when applicable First Amendment standards are quite general and leave considerable room for the exercise of judgment on the part of the trial court. ${ }^{187}$ In Globe Newspaper Co. v. Superior Court, for example, the Court held that First Amendment standards governing the closure of criminal trials entail a complex evaluation of numerous "factors," and that these standards require the exercise of "discretion" by the trial court. ${ }^{188}$ Yet the Court independently reviews decisions to close criminal trials to determine if trial judges have in fact used their judgment to come to the "right" constitutional conclusion. ${ }^{189}$ The rule of independent review thus gives appellate courts license to second guess the "weak discretion" that derives from the open-textured quality of certain constitutional standards. ${ }^{190}$.

The rule of independent review prohibits appellate courts from viewing trial court decisions as discretionary. In Rbinebart the Court explicitly rejected independent review, stating that "[i]t is sufficient for purposes of our decision that the highest court in the state found no abuse of discretion in the trial court's decision to issue a protective order pursuant to a constitutional state law." $191 \mathrm{~A}$ fair interpretation of this passage would be that although the First Amendment does not require appellate courts to exercise the rule of independent review, it does require, at a minimum, that appellate courts reviewing decisions to issue restraining orders employ an "abuse-of-discretion" standard.

When an appellate court reviews a trial court decision for abuse of discretion, it usually begins with a ritual incantation: "The question, of course, is not whether this Court, or whether the Court of Appeals, would as an original matter have [done $\mathrm{X}]$; it is whether

${ }^{187}$ See, e.g., Connick v. Myers, 103 S.Ct. 1684, 1692 n. 10 (1983); Nebraska Press Ass'n v. Stuart, 427 U.S. 539, 562 (1976).

188457 U.S. 596, 608-09 (1982).

${ }^{189}$ See Press-Enterprise Co. v. Superior Court, 104 S.Ct. 819, 824 (1984); Richmond Newspapers Inc. v. Virginia, 448 U.S. 555 (1980).

190 For a discussion of the intricate relationship between the rule of independent review and appellate court deference to trial court findings of fact, see Bose Corp. v. Consumers Union, 104 S.Ct. 1949, 1958-60 (1984).

191 104 S.Ct. at 2209. 
the District Court ábused its discretion in so doing."192 The incantation is meant to signify that review for abuse of discretion, unlike the rule of independent review, is designed to insulate a trial court's exercise of judgment from second-guessing by an appellate court. ${ }^{193}$ Appellate courts employ the abuse-of-discretion standard when they believe that the question before the trial court is susceptible of different satisfactory resolutions.

The abuse-of-discretion standard is commonly perceived to be incoherent. A noted commentator has suggested that " $[t]$ he phrase 'abuse of discretion' does not communicate meaning. It is a form of ill-tempered appellate grunting and should be dispensed with."194 One reason the standard is confused is that it encompasses two distinct situations that are almost never distinguished. In the first, which I shall call "deference," appellate courts retain control over the governing legal standard, but defer to trial court judgments in the implementation of that standard. In the second, which I shall call "delegation," appellate courts delegate to trial courts the power to determine the legal standards by which the correctness of their decisions will be judged.

If the standard of law to be applied has a sufficiently open texture, trial courts will have great latitude in choosing among alternative courses of action in situations of both deference and delegation. ${ }^{195}$ For this reason those who view discretion as the power to choose often conflate the two situations. Consider, for example, the comments of Judge Henry Friendly, in the context of a case concerning a trial court's discretionary power to dismiss a complaint without prejudice pursuant to Fed. R. Civ. P. 41(a)(2): ${ }^{196}$

[T] he fact that dismissal under Rule 41(a)(2) usually rests on the judge's discretion does not mean that this is always so. Several of the most important reasons for deferring to the trial judge's dis-

192 Insurance Corp. v. Compagnie des Bauxites, 456 U.S. 694, 707 (1982).

${ }^{193}$ This concept is often expressed by the formulation that "A review of a trial court's action in the exercise of discretion does not depend upon whether we would have reached the same conclusion, but rather upon whether, as a matter of law, there was an abuse of discretion." Rogers v. Lyle Adjustment Co., 70 N.M. 209, 372 P.2d 797, 800 (1962). See McManus v. Larson, 122 Cal. App. 716, 10 P.2d 523, 525 (1923).

${ }^{194}$ Rosenberg, note 158 supra, at 659; see Friendly, note 179 supra, at 763-64.

195 See, e.g., Curtiss-Wright Corp. v. General Electric Co., 446 U.S. 1, 10-11 (1980); Arizona v. Washington, 434 U.S. 497, 510 \& n.28 (1978).

196 Noonan v. Cunard Steamship Co., 375 F.2d 69, 71 (2d Cir. 1967). 
cretion-his observation of the witnesses, his superior opportunity to get 'the feel of the case,' . . . and the impracticability of framing a rule of decision where many disparate factors must be weighed- . . . are inapposite when a question arising in advance of trial can be stated in a form susceptible of a yes-or-no answer applicable to all cases.

Judge Friendly's underlying conception of discretion is that of choice. He speaks, for example, of "deferring to the trial judge's discretion." But this conception leads him to run together situations in which trial courts are given the power to choose because appellate courts cannot formulate "a rule of decision," with those situations in which trial courts are given the power to choose because of their superior access to pertinent facts such as "the feel of the case." 197 Judge Friendly overlooks the distinction between delegation and deference because each creates large areas free from the "surrounding belt of restriction," and he is primarily interested in the sweep, rather than the quality, of a trial court's freedom of choice.

Appellate court review in a situation of deference entails a tension between the articulation of a controlling legal standard and the preservation of a trial court's freedom of choice in the implementation of the standard. Appellate courts traditionally maintain this tension by enunciating a general legal "objective," such as the "interest in sound judicial administration," and then narrating the various factors that must be considered in attaining the objective. ${ }^{198}$ Irrespective of the outcome of a particular decision, appellate courts can then exercise review to determine if a trial court has in fact considered all the appropriate factors, ${ }^{199}$ or if it has considered certain inappropriate factors, ${ }^{200}$ or if it has failed to give certain factors appropriate weight. ${ }^{201}$ This kind of appellate control is precluded in

${ }^{197}$ Deference and delegation are similarly conflated in Friendly, note 179 supra, at 759-62, and in Rosenberg, note 158 supra, at 662-65.

${ }^{198}$ Curtiss-Wright Corp. v. General Electric Co., 446 U.S. 1, 10-11 (1980).

${ }^{199}$ See, e.g., United States v. Lewis, 482 F.2d 632, 643-44 (D.C. Cir. 1973); Wiggins v. United States, 386 A.2d 1171, 1174 (D.C. 1978); In re Adoption of Driscoll, 269 Cal. App. 2d 735, 75 Cal. Rptr. 382, 384 (1969).

${ }^{200}$ See, e.g., Arizona v. Washington, 434 U.S. 497, 510 n.28 (1978); United States v. Capriola, 537 F.2d 319, 320 (9th Cir. 1978); D.C. Federation of Civic Associations v. Volpe, 459 F.2d 1231, $1245-48$ (D.C. Cir. 1971), cert. denied, 405 U.S. 1030 (1972); United States v. Shaughnessy, 180 F.2d 489, 490 (2d Cir. 1950).

${ }^{201}$ Moses H. Cone Memorial Hospital v. Mercury Construction Corp., 103 S.Ct. 927, 938-39 (1983); Piper Aircraft Co. v. Reyno, 454 U.S. 235 (1981). 
situations of delegation, since trial courts are then authorized to determine which factors are legally pertinent for their decisions. ${ }^{202}$ Trial court discretion vis-à-vis appellate review is at its maximum in situations of delegation.

Although the Court in Rbinebart strongly implied that appellate courts reviewing decisions to issue restraining orders are constitutionally obligated to use an abuse-of-discretion standard, it did not address the question whether such review should involve deference or delegation. As a matter of state law, the Supreme Court of Washington appeared to address the question as one involving deference: ${ }^{203}$

Our understanding of the rule, contrary to that of the federal circuit courts in In re Halkin and In re San Juan Star Co., is that 'good cause' is established if the moving party shows that any of the harms spoken of in the rule is threatened and can be avoided without impeding the discovery process. In determining whether a protective order is needed and appropriate, the court properly weighs the respective interests of the parties. The judge's major concern should be the facilitation of the discovery process and the protection of the integrity of that process, which necessarily involves consideration of the privacy interest of the parties and, in the ordinary case at least, does not require or condone publicity.

The passage is ambiguous, since it requires trial courts to weigh "the respective interests of the parties," and yet it never explains what should count as a cognizable interest of the party receiving the discovery information. Although this might be taken as ceding authority to trial courts to develop standards concerning the interests of parties receiving information, the overall thrust of the passage (and the opinion) is clearly that decisions to issue restraining orders should be guided by a "major concern" to facilitate the discovery process and to protect its integrity. Thus the Washington court seems to have conceptualized the situation as one of deference.

The Supreme Court, like the Washington court, understood discretion to be primarily a matter of trial court flexibility and choice, and thus did not distinguish among grades of appellate control. The Court did assert, however, that trial court "discretion"

\footnotetext{
${ }^{202}$ See, e.g., INS v. Jong Ha Wange, 450 U.S. 139, 144-45 (1981).

${ }^{203} 654 \mathrm{P} .2 \mathrm{~d}$ at 690 . The Court reviewed the issuance of the restraining order under an abuse of discretion standard.
} 
is justified because the "trial court is in the best position to weigh fairly the competing needs and interests of parties affected by discovery," 204 and the Court did not enunciate any factors to be weighed in that balance. Since the Court also concluded that litigants retain First Amendment interests in the dissemination of discovery information, it is fair to surmise that the Court considered these interests to be so vague or diffuse as to be articulable only through the case-by-case determinations of the trial court. It would seem, therefore, that a state appellate court reviewing the issuance of a restraining order pursuant to Rule 26(c) would treat issues of state law as a matter of deference, but issues of federal constitutional law as a matter of delegation. The Supreme Court did not explain why these two kinds of issues should be treated differently.

\section{THE STRUCTURE OF DISCRETIONARY DECISIONS}

Because the abuse-of-discretion standard is indiscriminately applied in situations of both deference and delegation, it is forced to serve somewhat inconsistent functions. In situations primarily involving delegation, the abuse-of-discretion standard is construed to permit review only on the basis of a dilute and generous principle of background rationality, assumed to apply to all decision makers in all circumstances. ${ }^{205}$ In this modality, appellate courts characteristically say that "an abuse of discretion exists only when no reasonable person would take the position adopted by the trial court." ${ }^{206}$ Appellate courts sometimes add to the criterion of rationality the requirement that trial court decisions not be "the result of partiality, prejudice, bias, or ill will." ${ }^{207}$ Appellate courts also use

\footnotetext{
204104 S.Ct. at 2209.

${ }^{205}$ See Texas Indemnity Ins. Co. v. Arant, 171 S.W.2d 915, 919 n.1 (Tex. Civ. App. 1943).

${ }^{206}$ Griggs v. Averbeck Realty, Inc., 92 Wash. 2d 576, 599 P.2d 1289, 1293 (1979). See, e.g., Lemons v. St. John's Hospital, 5 Kan. App. 2d 161, 613 P.2d 957, 960 (1980) ("If reasonable men could differ as to the propriety of the action taken by the trial court, then it cannot be said that the trial court abused its discretion"); Moser v. Wilhelm, 300 N.W.2d 840,847 (N. Dak. 1981) ("An abuse of discretion is defined as an unreasonable, arbitrary, or unconscionable attitude on the part of the trial court").

${ }^{207}$ Mielcuszny v. Rosol, 317 Pa. 91, 176 A. 236, 237 (1934). See, e.g., Tobeluk v. Lind, 589 P.2d 873, 878 (Ala. 1979) ("We will not interfere with the trial court's determination unless it is shown that the court abused its discretion by issuing a decision which is arbitrary, capricious, marifestly unreasonable, or which stems from an improper motive").
} 
the abuse-of-discretion standard to ensure that trial courts understand that they have the power to exercise discretion, since "[f]ailure to exercise choice in a situation calling for choice is an abuse of discretion." 208

In situations primarily involving deference, the abuse of discretion standard is used by appellate courts to fulfill the very different function of enforcing applicable legal standards. Thus appellate courts will find an "abuse of discretion" if a trial court, in reaching its decision, entertained inappropriate considerations, ${ }^{209}$ or if it failed to entertain certain appropriate considerations, ${ }^{210}$ or if it did not appropriately weigh the factors it did consider. ${ }^{211}$

The abuse-of-discretion standard of review is thus used to preserve trial court flexibility and choice, and at the same time to screen trial court decisions for rationality, for improper motive or prejudice, and for compliance with pertinent legal principles. In order to perform these different functions; the abuse-of-discretion standard has been associated with a variety of devices designed to ensure that trial court decisions can be properly reviewed. These devices have been used in circumstances of both delegation and deference, although they appear to be more appropriately necessary in the latter situation.

Although an appellate court can review trial court decisions for abuse of discretion without requiring a record, findings, or any articulation of reasons, review in such circumstances can only be cursory. ${ }^{212}$ If an appellate court wishes to assure itself that a trial court has exercised its discretion, or has made a reasonable decision, or has followed controlling principles of law, the appellate court can prescribe that discretionary decision making be accom-

${ }^{208}$ Johnson v. United States, 398 A.2d 354, 363 (D.C. 1979). See Seibert v. Minneapolis \& St. Louis Ry. Co., 58 Minn. 58, 57 N.W. 1068, 1070 (1894); Grow v. Wolcott, 123 Vt. 490,194 A.2d 403, 404 (1963); Bowers, note 144 supra, at 37-49; $f$. Accardi v. Shaughnessy, 347 U.S. 260, 267-68 (1954).

${ }^{209}$ City of Elkhart v. Middleton, 265 Ind. 514, 356 N.E.2d 207, 211 (1976).

${ }^{210}$ Oppenheimer Fund, Inc. v. Sanders, 437 U.S. 340, 358-64 (1978).

2 II Piper Aircraft Co. v. Reyno, 454 U.S. 235 (1981). In situations of deference, appellate courts will characteristically defer to trial court judgments in the implementation of legal standards so long as these judgments are not "clearly unreasonable." Curtiss-Wright Corp. v. General Electric Co., 446 U.S. 1, 10 (1980).

212 See Link v. Wabash Railroad Co., 370 U.S. 626(1962); Woodruff v. Woodruff, 7 Ohio Misc. 87, 217 N.E.2d 264, 268 (1965). 
panied by procedures to enhance reviewability. Appellate courts can require that there be a "rational basis in the evidence" to support a trial court's discretionary decision; ${ }^{213}$ or they can compel a trial court to "disclose, by specific findings, the basis for its ultimate conclusion"; ${ }^{214}$ or they can mandate "that the exercise of discretion be accompanied by the trial court's articulation of the factors considered and the weight accorded to them."15

By conibining these various devices, and by enforcing them, appellate courts can give teeth to the abuse-of-discretion standard of review. While such rigor is ordinarily associated with judicial review of administrative discretion, ${ }^{216}$ it has also been applied to appellate review of judicial discretion in the pretrial management of a case. In Gulf Oil Co. v. Bernard, ${ }^{217}$ for example, the Supreme Court used the abuse-of-discretion standard to review the issuance of a restraining order that essentially prohibited nanied plaintiffs and their counsel from communicating with any actual or potential plaintiff class menibers. ${ }^{218}$ The Court did not reach the question of the order's constitutionality, ${ }^{219}$ but instead held that the trial court had "abused its discretion" because it had issued the order without "a clear record and specific findings that reflect a weighing of the

${ }^{213}$ In re Coordinated Pretrial Proceedings in Petroleum Products Antitrust Litigation, 669 F.2d 620, 623 (10th Cir. 1982). See Curtiss-Wright Corp. v. General Electric Co., 446 U.S. 1,10 (1980).

${ }^{214}$ Grow v. Wolcott, 123 Vt. 490, 194 A.2d 403, 407 (1963).

${ }^{215}$ United States v. Criden, 648 F.2d 814, 819 (3d Cir. 1981). See Hartung v. Hartung, 102 Wis. 2d 58, 306 N.W.2d 16, 21 (1981); City of Elkhart v. Middleton, 265 Ind. 514, 356 N.E.2d 207, 210 (1976). Judge Friendly has strongly argued that in situations of deference trial courts should be required to make explicit the grounds of their "discretionary" decisions: "Once it has been deemed appropriate to limit the range of discretion, whether through announcement of a principle of preference or the specification of factors, it becomes necessary that the trial court articulate the basis for its decision. Otherwise it will not be possible for an appellate court to determine whether the trial court's decision rest on an application of the proper rule or the mistaken assumption of some other rule." Friendly, note 179 supra, at 770 .

${ }^{216}$ See, e.g., Burlington Truck Lines, Inc. v. United States, 371 U.S. 156, 167-68 (1962); Motor Vehicle Mfrs. Ass'n v. State Farm Mut., 103 S.Ct. 2856, 2866-67 (1983).

217452 U.S. 89 (1981).

${ }^{218}$ The restraining order was issued pursuant to Fed. R. Civ. P. 23(d), which authorizes judicial management of class actions.

219452 U.S. at $101 \mathrm{n} .15$. The Court stated: "[A]lthough we do not decide what standards are mandated by the First Amendment in this kind of case, we do observe that the order involved serious restraints on expression. This fact, at minimum, counsels caution on the part of a district court in drafting such an order, and attention to whether the restraint is justified by a likelihood of serious abuses." Id. at 103-04. 
need for limitation and the potential interference with the rights of the parties."220

The Court offered three reasons to justify the imposition of these requirements. First, the requirements would help create a "record useful for appellate review." 221 Second, they were necessary to "ensure that the court is furthering, rather than hindering, the policies embodied in the Federal Rules of Civil Procedure."222 Third, and most interesting, the requirements would force the trial court to engage in a process of balancing in the course of which it would have explicitly to identify "the potential abuses being addressed." 223 In this manner the process of trial court choice could be structured so as to increase the likelihood that it would "result in a carefully drawn order that limits speech as little as possible, consistent with the rights of the parties under the circumstances." 224

Bernard thus suggests that certain structural prerequisites can be imposed on discretionary decision making both to enhance the quality of decision making and to increase the chances of meaningful appellate review. I shall call these prerequisites "accountability requirements." Accountability requirements may have value even if trial court decisions entail the exercise of weak discretion and are discretionary from the point of view of appellate review.

The Court in Rbinebart did not explicitly address the issue of accountability requirements. It did not explain whether trial courts issuing restraining orders would be constitutionally required to compile a record, issue findings, or articulate "the need for a limitation and the potential interference with the rights of the parties."225 It is thus open to question whether the First Amendment compels these accountability requirements to "ensure that the [trial] court is furthering, rather than hindering," its policies.

\footnotetext{
${ }^{220} \mathrm{Id}$. at $10 \mathrm{I}$.

221 Id. at 102.

222 Ibid.

223 Ibid.

${ }^{224}$ Id. at 102. See Johnson v. United States, 398 A.2d 354, 364 (D.C. 1979): "In both the judicial and administrative spheres the requirement that the decision-maker compile a record makes certain that the facts of the case do not escape his attention and makes it more probable that the decision-maker will exercise his discretion in a proper manner." See also DAvis, note 2 supra, at 97-141.

${ }^{225}$ The facts of Rbinebart are ambiguous. Although the trial judge made no specific findings, he did issue an opinion justifying entry of the restraining order. And the record in the case clearly provides a rational basis for the decision to issue the order.
} 
V. The First Amendment, Discretion, AND the MANAGEMENT OF PRETRIAl DisCovery

If restraining orders can appropriately be characterized as an internal management tool of the judicial system, they will be constitutional if necessary for achievement of the system's legitimate ends. This is true even though restraining orders constitute prior restraints and depend on the content of litigants' speech. The question remains, however, whether any particular restraining order is necessary for the supervision of pretrial discovery. The implicit position of Rule 26(c) is that effective administration of pretrial discovery requires that the answer to this question be committed to the discretion of trial judges. In Rhinebart the Supreme Court affirmed this position.

But this position is far too coarse to serve as a basis for constitutional analysis, both because it fails to distinguish among the various dimensions of discretion, and because it fails to appreciate that discretion is a matter of degree. More careful analysis would require an inquiry into the nature and extent of trial court discretion claimed to be necessary for effective pretrial administration.

\section{A. RESTRAINING ORDERS AND "WEAK" DISCRETION}

"Weak" discretion exists when a controlling legal standard is so open textured or general that its implementation requires the exercise of judgment. The First Amendment ordinarily limits weak discretion by requiring that legal standards authorizing the suppression of speech "set reasonably clear guidelines for law enforcement officials and triers of fact in order to prevent 'arbitrary and discriminatory' enforcement."226 But some weak discretion is both unavoidable and constitutionally permissible. In Feiner $v$. New York, for example, the Court upheld the exercise of a "police officer's proper discretionary power" to suppress speech on the basis of a constitutional breach-of-the-peace statute. ${ }^{227}$ At some

\footnotetext{
${ }^{226}$ Smith v. Goguen, 415 U.S. 566, 573 (1974).

227340 U.S. 314,319 (1951). Similarly, the Court has held that statutes governing decisions to issue parade or demonstration permits can be general enough to leave room for the "discretion" of a decision maker, so long as that discretion is limited to appropriate considerations of "time, place and manner." Cox v. New Hampshire, 312 U.S. 569, 575-76 (1941). See Cox v. Louisiana, 379 U.S. 536, 558 (1965).
} 
point, however, controlling legal standards become so general as to leave "unfettered discretion"228 in the hands of government officials, and this is constitutionally impermissible since speech might then be penalized on the basis of "personal predilections." 229

There is no sharp line at which weak discretion passes into constitutionally forbidden license. ${ }^{230}$ In the regulation of the speech of the general public, the Court's analysis of weak discretion can most kindly be described as confused. In the regulation of insubordinate speech, however, the distinction between permissible and impermissible weak discretion is tied to a functional analysis of the institutional authority in question. Weak discretion is constitutional when it is "necessary to the furtherance" of institutional goals. ${ }^{231}$ As the Court said in a case challenging military regulation of speech as delegating excessive weak discretion: "For the reasons which differentiate military society from civilian society, we think Congress is permitted to legislate both with greater breadth and with greater flexibility when prescribing the rules by which the former shall be governed than it is when prescribing rules for the latter."232

Management situations characteristically involve weak discretion. This is because strict rules that leave no room for judgment in their implementation are unsuitable "where the action to be controlled is non-recurring" and in circumstances involving "personalized, individual application." ${ }^{233}$ When rules are strictly applied in such situations, they can create an "unreasonableness"234 that is fierce, unproductive, and "bureaupathic."235 Morris Cohen long ago captured the dilemma "felt by every one who has to give orders to a human subordinate. You attempt to guard yourself

\footnotetext{
${ }^{228}$ Papachristou v. City of Jacksonville, 405 U.S. 156, 168 (1972).

${ }^{220}$ Kolender v. Lawson, 103 S.Ct. 1855, 1858-59 (1983).

${ }^{230}$ See Amsterdam, The Void-for-Vaguteness Doctrine in the Supreme Court, 109 U. PA. L. REv. 67, 94-96 (1960). In part the placement of this line depends upon whether, "by the nature of the problems presented, legislatures simply cannot establish standards with great precision." Smith v. Goguen, 415 U.S. at 581.

${ }^{231}$ Procunier v. Martinez, 416 U.S. 396, 416-18 (1974).

232 Parker v. Levy, 417 U.S. 733, 756 (1974).

233 Jowell, note 182 supra, at 202. See PERRow, note 127 supra, at 162-63. Most management situations involve precisely such nonrecurring circumstances demanding the exercise of personal judgment. See KOTTER, THE GENERAL MAANAGERS 122-24 (1982).

${ }^{234}$ Bardach \& Kagan, Gong by the BoOK: The Problem of Reglilatory UNREASONABLENESS 58-119 (1982).

${ }^{235}$ Thompson, MOdern Organization 94 (1977).
} 
against his mistakes or departures from your settled policy by laying down fixed rules. But when your subordinate rigorously follows these rules, you are vexed that he does so mechanically without using common sense or judgment."236

Most organizations want their managers to use their common sense and consequently prescribe fixed rules sparingly, tending instead to control their managers by setting general objectives or goals which the managers are expected to meet. ${ }^{237}$ The more managerial performance is defined by its product or outcome, "the more discretion" is given the manager "to supply the means-ends connections."238

These considerations apply to judicial management of pretrial discovery. Pretrial discovery involves nonrecurring situations filled with "multifarious, fleeting, special, narrow facts that utterly resist generalization. ${ }^{239}$ It involves the continual exercise of judgment, ${ }^{240}$ the continual assessment of the intentions, goals, and good faith of litigants; ${ }^{241}$ and it is for these reasons "not amenable to regulation by rule." ${ }^{242}$ As a consequence both the Washington and the Federal rules of civil procedure do not prescribe detailed and mechanical rules to govern the management of pretrial discovery, and instead provide trial judges with the power and flexibility necessary to attain broadly stated institutional goals. ${ }^{243}$

To impose strict rules on the issuance of restraining orders would impose deep costs of unreasonableness and managerial inefficiency. The circumstances requiring issuance of such orders are simply too

${ }^{236}$ COHEN, LAw AND The SOCIAL ORder 262 (1982).

${ }^{237}$ See, e.g., Drúcker, Management: Tasks, Responsibilities, Practices 430-42 (1973); Galbraith, Organization Design 45-46 (1977); Odiorne, Manageievt DeCISIONS BY OBJECTIVES (1969).

${ }^{238} \mathrm{MARCH} \&$ SiMON, note 128 supra, at 147.

${ }^{239}$ Rosenberg, note 158 stupra, at 662.

${ }^{240}$ See text at notes $114-17$ supra.

${ }^{241}$ See, e.g., Resnik, note 111 supra, at 393.

242 Rosenberg, note 158 supra, at 662 . William Glaser, in his study of pretrial discovery, concluded: "Rules cannot anticipate every situation and supply detailed guidelines; the rules must have administrators who distinguish the legitimate from the illegitimate complaint and who can manage each situation." GLASER, note 116 supra, at 237.

${ }^{243}$ The Supreme Court of Washington stated that "the purpose of the discovery rule [is] to encourage full disclosure of all relevant facts so as to facilitate the administration of justice, acquaint the examiner with the testimony that will be given at trial, develop the truth, shorten and simplify the trial, eliminate elements of surprise, and permit the parties to prepare for trial." 654 P.2d at $678-79$. 
multifarious to be encompassed by any set of specific rules. The issue is not simply that a regime of strict, mechanical rules would impair the ability of trial courts to issue restraining orders when appropriate, but also that this impairment would adversely affect the capacity of trial judges to manage other aspects of pretrial discovery. Trial judges presently have broad discretion to control the exchange of discovery information so as to attain the general goals of pretrial discovery. But to the extent that strict rules are imposed on restraining orders, discretion to manage the exchange of information will also be constricted. Even if judges believe that pertinent discovery information should be produced, they may be unwilling to require its production if the presence of inflexible rules disables them from ensuring that such information will be properly used.

Even the Halkin opinion does not attempt to impose a regime of strict rules on the issuance of restraining orders, but rather proposes a series of general First Amendment principles meant to inform the judgment of trial judges. ${ }^{244}$ The trial judge is instructed to consider factors like the nature of the First Amendment interests at stake and the extent of the harm to be averted. ${ }^{245}$ It is perfectly proper to conceive First Amendment principles as ceding such weak discretion to trial judges. The Supreme Court has even held that with regard to the administrative decision to close a criminal trial, the First Amendment requires that trial judges exercise weak "discretion" so that their judgment may most accurately reflect the particular circumstances involved. ${ }^{246}$

Two consequences follow from this reasoning. First, the Court's conclusion in Rhinebart that the First Amendment does not prohibit Rule 26(c)'s delegation of "broad discretion" seems essentially correct. Although Rule 26(c) makes no effort to specify "narrow, objective and definite standards"247 to govern the issuance of restraining orders, any attempt to do so would likely cripple trial courts' ability effectively to manage the pretrial exchange of discovery information. Second, the First Amendment standard governing

\footnotetext{
${ }^{244}$ See Brink v. DaLesio, 82 F.R.D. 664, 678 (D. Md. 1979).

245598 F.2d at 191. The court stressed that these considerations must be evaluated in the context of "particular discovery material and a particular trial setting." Id. at 195.

${ }^{246}$ See Globe Newspaper Co. v. Superior Court, 457 U.S. 596, 608-10 (1982).

247 Shuttlesworth v. Birmingham, 394 U.S. 147, 151 (1969).
} 
the issuance of restraining orders should not itself contain specific standards. It would have been sufficient for the Court to have made clear that restraining orders seriously infringe litigants' First Amendment interests, and that this infringement should not take place unless necessary to attain the goals of pretrial discovery.

\section{B. RESTRAINING ORDERS AND APPELLATE CONTROL}

The issue that most sharply divides Halkin and Rhinehart is the degree of appellate control that should be exercised over decisions to issue restraining orders. ${ }^{248}$ Halkin holds that appellate courts should apply the rule of independent review to such decisions; Rbinebart decides that appellate courts can view such decisions as involving a situation of delegation.

The Supreme Court's decision is plainly incorrect. Appellate courts normally treat trial court management of pretrial discovery as a question of deference, and indeed the Supreme Court of Washington has indicated that decisions to issue restraining orders under Rule 26(c) should be so viewed as a matter of state law ${ }^{249}$ Since there is an articulable First Amendment standard that should govern decisions to issue restraining orders, there is no justification for the Supreme Court's view that appellate courts treat such decisions as raising issues of delegation rather than of deference. The most that can reasonably be maintained is that appellate courts should retain control over the articulation of the applicable First Amendment standard, but should defer to trial courts in its implementation. The question is thus whether appellate courts should apply

${ }^{248}$ Thus one perceptive federal district court noted that the factors to be considered under Halkin's First Amendment standard, and the factors to be considered under federal Rule 26(c)'s "good cause" standard, were virtually "identical." The real difference, the Court stated, "lies in the discretionary nature of the good cause standard. In determining whether there is good cause to enter a Rule 26(c) order, a court may, but does not have to, weigh these factors. Moreover, because a determination that good cause has been shown is reviewed under an abuse of discretion standard, it is less likely that the appellate court would substitute its judgment for that of the trial court even if, for example, it believed that more deference should have been given to the other party's First Amendment interests. Under ... the [First Amendment standard], on the other hand, the court must find that definite criteria have been satisfied before issuing a protective order, and failure to do so will result in a reversal. To the extent that the discretion of the trial court is limited by [the First Amendment], therefore, [it] provide[s] more protection for a litigant's First Amendment rights." Koster v. Chase Manhattan Bank, 93 F.R.D. 471, 479-80 (S.D.N.Y. 1982).

${ }^{249}$ See text at note 203 supra. 
the rule of independent review, or whether they should exercise deference.

Appellate courts normally view the management of pretrial discovery with considerable deference because trial courts are "in a far better position than a court of appeals to supervise and control discovery." 250 When First Amendment considerations are present, however, appellate courts ordinarily view trial court decisions as raising issues of law. In Nebraska Press Ass'n v. Stuart, for example, the Court applied the rule of independent review to a trial court decision to issue a gag order, even though the order was issued by a trial court that could be said to have had a more sensitive "feel for the case" than any appellate court. The Court, moreover, exercised independent review even though the First Amendment standard controlling the issuance of the gag order was extremely vague and involved the balancing of several factors. ${ }^{251}$ Indeed, as the Court recently stressed, the rule of independent review is founded on the necessity of creating a check on the exercise of weak discretion arising from the generality of First Amendment standards: ${ }^{252}$

Providing triers of fact with a general description of the type of communication whose content is unworthy of protection has not, in and of itself, served sufficiently to narrow the category, nor served to eliminate the danger that decisions by triers of fact may inhibit the expression of protected ideas. The principle of viewpoint neutrality that underlies the First Amendment itself ... also imposes a special responsibility on judges whenever it is claimed that a particular communication is unprotected.

Thus whenever trial courts determine that speech is obscene, or uttered with actual malice, or constitutes fighting words, such determinations are reviewed by appellate courts as posing questions of law, and this enables appellate courts to determine if these questions have been rightly or wrongly decided. ${ }^{253}$ The Court of Appeals in Halkin saw no reason to treat appellate review of restraining orders any differently. This position is attractive in the light of the extensive weak discretion characterizing decisions to issue restraining orders.

${ }^{250}$ ACF Industries, Inc. v. EEOC, 439 U.S. 1081, 1087 (1979) (Powell, J., dissenting from denial of certiorari).

251427 U.S. 539, 562 (1976).

252 Bose Corp. v. Consumers Union, 104 S.Ct. 1949, 1962 (1984).

${ }^{253}$ Id. at 1961-63. 
The rule of independent review, however, is not invariably applied to the regulation of First Amendment rights. In Glines, for example, the Court was willing to defer to military judgment concerning the censorship of speech. ${ }^{254}$ This deference cannot simply be interpreted as the respect owing to the "expertise" of those charged with the administration of government institutions. In Tin$k e r$ the Court refused to defer to the managerial authority of a state school board. School officials are presumably as expert in the administration of their institution as military officials are in the management of theirs. The difference must therefore be attributed to the Court's assessment of the need for deference in the achievement of legitimate institutional goals. ${ }^{255}$

The issue presented in Rbinebart is therefore whether applying the rule of independent review to the issuance of restraining orders would impair the capacity of trial courts to manage pretrial discov-

${ }^{254}$ The Court reached a similar conclusion in Jones v. North Carolina Prisoners' Union, 433 U.S. 119 (1977), in which the Court upheld the authority of prison officials to suppress First Amendment interests on the basis of "fears as to future disruptions" as long as such fears were not "groundless." Id. at 127 n.5, 132-33. The Court concluded that such weak discretion was necessary because of "the reasonable considerations of penal management" and the "self-evident" interest in "preserving order and authority in prisons." Id. at 132, 136. In reviewing the suppression of First Amendment rights, a "wide-ranging deference" was "to be accorded the decisions of prison administrators." Id. at 126. "The necessary and correct result of our deference to the informed discretion of prison administrators permits them, and not the courts, to make the difficult judgments concerning institutional operations in situations such as this." Id. at 128. In Connick v. Myers, 103 S.Ct. 1684 (1983), on the other hand, the Court was ambivalent about whether it should defer to decisions to regulate the speech of government employees. The Court noted that if employee expression were only marginally related to matters of public concern, and if such expression "interfered with working relationships" in a situation where "close working relationships are essential to fulfilling public responsibilities," "a wide degree of deference to employer's judgment is appropriate. Furthermore, we do not see the necessity for an employer to allow events to unfold to the extent that the disruption of the office and the destruction of working relationships is manifest before taking action. We caution that a stronger showing may be necessary if the employee's speech more substantially involved matters of public concern." Id. at 1692-93.

${ }^{255}$ In Tinker the Court's refusal to defer to the judgment of school officials did not necessarily extend to all school decisions regulating speech. Underlying the Court's opinion was the notion that school authority over speech had definite limitations. The Court stated, for example, that "[i]f a regulation were adopted by school officials forbidding discussion of the Vietnam conflict, or the expression by any student of opposition to it anywhere on school property except as part of a prescribed classroom exercise, it would be obvious that the regulation would violate the constitutional rights of students, at least if it could not be justified by a showing that the students' activities would materially and substantially disrupt the work and discipline of the school." 393 U.S. at 513. The Court appears to have viewed the ban on black armbands as just such a regulation. That the Court refused to defer to it does not imply that it would also refuse to defer to different regulations that were within what the Court was prepared to acknowledge as the legitimate authority of the school, as for example those that occur in classroom settings. 
ery. This issue can be analyzed by precisely defining the objectives served by the rule of independent review. Upon close inspection, the Court is notably vague as to the nature of these purposes. It says only that "[w]hen the standard governing the decision of a particular case is provided by the Constitution, this Court's role in marking out the limits of the standard through the process of caseby-case adjudication is of special importance."256 But of what importance? There are two possibilities.

The importance of the rule of independent review might lie in the fact that the "process of case-by-case adjudication," through the classic alchemy of the common law, will eventuate in the enunciation of principles of law that are increasingly specific and strict, thus gradually reducing the weak discretion implicit in general First Amendment standards. ${ }^{257}$ But to the extent that the rule serves this purpose, its function is ultimately to restrict the managerial flexibility of the trial judge in the supervision of pretrial discovery. If it is important to preserve such flexibility, then it would be better to forestall this process of "case-by-case" adjudication by imposing a rule of deference.

On the other hand, the "special importance" of the rule of independent review might refer not to its role in the development of more specific standards, but rather to its role in ensuring that justice is done in the individual case. If the general nature of First Amendment principles creates the danger that judgment to suppress speech might be exercised in a biased or improper manner, the function of the rule of independent review might be to oversee the exercise of judgment in each case so as to correct any such errors or bias. Independent review would thus undo the effects of improper suppression of speech.

If the rule of independent review is to serve this function, however, appellate review of restraining orders should be interlocutory in nature. This is because damage to First Amendment interests arises not merely from the outright suppression of speech, but also

\footnotetext{
${ }^{256}$ Bose Corp. v. Consumers Union, 104 S.Ct. at 1961.

${ }^{257}$ Thus Morris Cohen has observed: "Discretion, in general, represents more or less instinctive evaluation or appreciation of the diverse elements that enter into a complex; and such instinctive evaluation must precede conscious rulemaking. Rules are the limits that the continued exercise of discretion establishes." COHEv, note 236supra, at 264. See Albermarle Paper Co. v. Moody, 422 U.S. 405, 413-21 (1975); Cross, PreCEdent in ENGlish LAW 214-16 (2d ed. 1968).
} 
from government action which temporarily delays expression. ${ }^{258}$ An erroneous restraining order imposes additional damage for every day that it remains in effect. For this reason the Court has interpreted the First Amendment to require "immediate appellate review" of judicial orders suppressing speech. ${ }^{259}$ If the purpose of the rule of independent review were to vindicate constitutional rights, it too should be "immediate." Halkin clearly appreciated this logic, for it held that restraining orders should be subject to immediate appellate review through the extraordinary writ of mandamus. ${ }^{260}$

To permit interlocutory appeals of restraining orders would work a basic change in discovery practice. Under the law of most jurisdictions, appeals are not allowed as a matter of right except from final judgments. ${ }^{261}$ Judicial orders regulating discovery, including restraining orders, are interlocutory and not appealable as a matter of right until the ultimate disposition of a case. ${ }^{262}$ The reasons for this policy were stated by the Court in Cobbledick v. United States: $: 263$

Congress from the very beginning has, by forbidding piecemeal disposition on appeal of what for practical purposes is a single controversy, set itself against enfeebling judicial administration. Thereby is avoided the obstruction to just claims that would come from permitting the harassment and cost of a succession of separate appeals from the various rulings to which a litigation may give rise, from its initiation to entry of judgment. To be effective, judicial administration must not be leadenfooted. Its momentum would be arrested by permitting separate reviews of the component elements in a unified cause.

${ }^{258}$ See, e.g., Freedman v. Maryland, 380 U.S. 51 (1965); Carroll v. President and Commissioners of Princess Anne, 393 U.S. 175, 182 (1968); Nebraska Press Ass'n v. Stuart, 427 U.S. at 559.

${ }^{259}$ National Socialist Party of America v. Skokie, 432 U.S. 43, 44 (1977).

260598 F.2d at $197-200$.

${ }^{261}$ STERn, APPELlate Practice in the United STATes 52-54 (1981); Glass v. Stahl Specialty Co., 97 Wash. 2d 880, 883, 652 P.2d 948 (1982).

${ }^{262}$ See Bushman v. New Holland Div. of Sperry Rand Corp., 83 Wash. 2d 429, 518 P.2d 1078, 1079-80 (1974); Washington v. Superior Court, 193 P.2d 318, 319 (Wash. 1948); Haydock \& Herr, Discovery: Theory, Practice and Problems 311-14 (1983). See, Cutner, note 120 supra, at 947-48; Resnick, note 111 supra, at 411-14; International Products Corp. v. Koons, 325 F.2d 403, 406-07 (2d Cir. 1963). Rbinebart was heard on appeal pursuant to a Washington rule permitting discretionary review of interlocutory decisions. See R.A.P. 2.3.

263309 U.S. 323, 325 (1940). See Coopers \& Lybrand v. Livesay, 437 U.S. 463, 467 n.8 (1978); Firestone Tire and Rubber Co. v. Risjord, 449 U.S. 368, 373-74 (1981). 
For these reasons, the ability of trial courts to manage pretrial discovery would be substantially impaired if restraining orders were to be routinely reviewable on interlocutory appeal. ${ }^{264}$ Every time a trial court decided to condition discovery upon the issuance of a restraining order, the pretrial conduct of the case could potentially come to a halt during the months or perhaps years required for prosecution of an "immediate" appeal. ${ }^{265}$ Trial courts would think twice about issuing restraining orders, and their usefulness as tools of pretrial management would be pro tanto diminished. The inner logic of the rule of independent review, therefore, when applied in the context of restraining orders, would tend toward conclusions that substantially impair the management flexibility of trial judges.

Despite this logic, it nevertheless can be contended that appellate courts should offer noninterlocutory independent review on the grounds that an ultimately correct disposition, however delayed, will be of importance to particular litigants. There are two considerations that weigh against this contention. The rule of independent review presupposes that appellate courts can scrutinize facts and law to determine the "correct" legal outcome. But each time an appellate court announces such an outcome, it establishes a precedent that will be binding on future trial court decisions. The accumulation of such precedents will in the end erode the weak discretion necessary to govern pretrial discovery. Appellate court deference, on the other hand, significantly diminishes both the number and force of such precedents.

It is not clear, moreover, that the question whether a restraining order should issue has any uniquely "correct" legal outcome. It is possible, for example, for a trial court to issue a restraining order

$26+$ The State of New York at present permits discovery orders to be appealed as a matter of right, and the general consensus is that this practice "is a prime source of delay and expense in litigation." Korn, Civil Jurisdiction of the New York Court of Appeals and Appellate Divisions, 16 BUf. L. Rev. 307, 330, 332-33 (1966-67). See 7 WeInSTEIN, KorN, \& MILLER, NEW YORK CIVIL PRACTICE $\$ 5701.03$ (1983). During the debate surrounding the enactment of 28 U.S.C. § 1292(b) (discretionary appeal), Charles E. Clark strongly "argued that 'upper-court policing of trial court activity is not a sound appellate function and, in view of its haphazard and freezing characteristics, can only be detrimental to effective court administration.' " Fish, note 120 supra, at 109. Clark viewed the availability of interlocutory appeals as creating the possibility of litigation strategies designed to erode an "adversary's powers of resistance." Ibid.

${ }^{265}$ A prime example is Halkin itself. The District of Columbia Circuit did not issue its decision until almost two years after the trial court had signed the restraining order. 
because particular litigants are uncooperative and need to be kept on a short leash, ${ }^{266}$ or because the bar practicing before it needs to be taught an object lesson. ${ }^{267}$ These are classic managerial considerations, and they neither seem amenable to any uniquely correct legal solution, nor do they seem susceptible to appellate court determination. If such considerations are legitimate, it is not clear whether independent review can perform any useful function.

These objections are not dispositive, but when they are raised in a context in which the inner logic of independent review has been truncated, they provide support for the Court's conclusion that decisions to issue restraining orders constitutionally need only be reviewed under an abuse of discretion standard.

\section{RESTRAINING ORDERS AND ACCOUNTABILITY REQUIREMENTS}

The abuse-of-discretion standard is a mansion with many rooms. One such room, as Gulf Oil Co. v. Bernard makes clear, is the prescription that trial court decisions be made on the basis of "a clear record and specific findings that reflect a weighing of the need for a limitation and the potential interference with the rights of the parties." This prescription imposes three distinct accountability requirements on trial court decision making. Decisions must be supported by a record; they must be based upon specific findings; and there must be an articulation of the reasons for the decision. Imposing these requirements serves two purposes: it improves the quality of trial court decision making by forcing trial judges to reach decisions in a careful and self-conscious manner, and it provides a sufficient record for meaningful appellate review.

Decisions to issue restraining orders plainly can interfere with First Amendment rights. It would therefore appear to be constitutionally important to impose the Bernard requirements on such decisions if they would reduce the likelihood of improper restraining orders. The Halkin decision appears to have imposed some of these requirements, stating that trial courts must make "necessary findings" with respect to each element of the appropriate First Amendment standard. ${ }^{268}$ The Court in Rbinebart, on the other hand, ap-

\footnotetext{
266 See text at note 115 supra.

267 See text at notes 113,117 supra.

268598 F.2d at 1892.
} 
parently decided not to impose such requirements, stating in a cryptic footnote that "heightened First Amendment scrutiny of each request for a protective order" was inappropriate because it "would necessitate burdensome evidentiary findings." 269

The Court's point is obscure. It might be that the Bernard requirements are so burdensome that they unduly restrict the flexibility necessary for pretrial management of a case. But why are these requirements compatible with effective pretrial management in Bernard, but not in Rbinebart? 'The Court's response is suggested by its citation ${ }^{270}$ of Zenith Radio Corp. v. Matsusbita Elec. Indus. Co., a large antitrust case involving a restraining order covering "millions of pages of documents produced in discovery."271 If the First Amendment were to require the trial court in Zenitb to make findings, articulate reasons, and compile a record with respect to each of these pages of discovery information, the burden would clearly be overwhelming. That result calls to mind the blunt observation of a California district judge who refused to entertain a motion to vacate a restraining order covering "massive quantities of documents": "I might . . . require that defendants now justify the protective order as to each item which they believe should be protected. Some person would then be required to pass upon those justifications. I do not propose to be that person."272

The Court's concern for the special problems caused by large cases seem appropriate, but not insurmountable. It would be senseless to impose accountability requirements in a self-defeating fashion. In a case involving vast quantities of discovery information, it may be perfectly appropriate for a trial court to structure its decision to issue a restraining order on the basis of generic categories of documents, rather than on the basis of an item by item review. This is the present practice of those courts which interpret the "good cause" standard of Rule 26(c) to "require a particular and specific demonstration of fact." 273 Even Halkin conceded that in an appropriate case a trial court could issue "a blanket protective order

269104 S.Ct. at 2209 n. 23.

${ }^{270}$ Ibid.

271529 F. Supp. 866, 874 (E.D. Pa. 1981).

272 In re Coordinated Pretrial proceedings in W. Liquid Asphalt Cases, 18 F.R.Serv. 2d 1251, 1252 (N.D. Cal. 1974).

${ }^{273}$ See note 55 supra and the cases cited. 
covering all documents in a large-scale exchange of files without prejudice to raising the merits of the protective order as applied to particular documents at a later time." 274 If accountability requirements are interpreted to apply in a reasonable fashion-which is to say, if they are interpreted not to impose an undue burden on trial courts - there does not appear to be any good reason to view them as inconsistent with effective trial court management of pretrial discovery.

One can ask, however, whether these accountability requirements contribute so significantly to the quality of trial court decision making as to justify their being imposed as a constitutional prerequisite. While there is no empirical evidence on this issue, it does seem plain that imposing special requirements on decisions affecting First Amendment interests invests these decisions with a gravity and importance commensurate with the constitutional issues at stake. Requiring decisions to issue restraining orders to meet the Bernard accountability requirements will distinguish these decisions from the "informal" atmosphere in which ordinary pretrial administrative decisions are made. ${ }^{275}$ This is itself important, and it is also noteworthy that the Court has in other contexts required trial court decisions affecting First Amendment rights to be accompanied by specific findings and an articulation of reasons. Administrative decisions to close criminal trials are, for example, subject to such requirements. ${ }^{276}$

Even if these requirements only marginally improve the quality of trial court decision making, it would seem especially important to impose them on decisions to issue restraining orders, since such decisions are reviewed only for abuse of discretion and hence are unlikely to be reversed on appeal. Indeed, to the extent that the abuse-of-discretion standard is weak, it would also seem particularly appropriate that trial court decisions be accompanied by an articulation of reasons and specific findings, so that appellate courts will be more likely to detect erroneous interpretations of the controlling legal standard. This was the logic of Bernard, and it should

\footnotetext{
274598 F.2d at 196 n.47.

275 See Resnick, note 111 supra, at 407.

276 See Press-Enterprise Co. v. Superior Court, 104 S.Ct. 819, 824 (1984); Globe Newspaper Co. v. Superior Court, 457 U.S. 596, 608 n.20 (1982).
} 
have redoubled application in the constitutional context of restraining orders.

The facilitation of appellate court review can, however, have adverse consequences. To the extent that accountability requirements further the creation of more and firmer appellate precedents, they can also contribute to the erosion of weak trial court discretion. Appellate courts have also been known to use accountability requirements as a bootstrap to increase the rigor of appellate review. These dynamics have in fact fueled much of American administrative law. ${ }^{277}$ But accountability requirements are unlikely to generate similar dynamics in the area of restraining orders. This is because of the long and honored tradition of respecting trial court discretion in the pretrial management of a case. The tradition is stable because appellate courts trust trial judges in a way that they have never trusted administrators. As a former judge of the Court of Appeals for the Second Circuit put it: "I . . . begin with the assumption that federal judges are men of high purpose who exercise authority in the best interests of justice as they see it. If this were not so, the wide range of discretion that was left to district judges by the Rules would not have been left to them." ${ }^{278}$ A similar assumption underlies the Court's opinion in Rbinehart, and it provides good reason to believe that appellate courts will not use accountability requirements to undermine necessary trial court discretion.

\section{CONCLUSION}

This may suggest a conclusion that is, in the main, similar to that intuitively attained by the Court in Rbinebart. That the Court should have reached this conclusion is remarkable, for it flies in the face of much received First Amendment wisdom. Restraining orders are prior restraints, they are based upon the content of speech, and they are issued at the discretion of a state official. The Court's disregard of these facts demonstrates the strength instinctively attributed to government interests in the internal management of

277 See, e.g., Sunstein, Deregulation and the Hard-Look Doctrine, 1983 SUPREME COURT REVIEW 177, 181-84, 209-12.

${ }^{278}$ Waterman, An Appellate Judge's Approacb Wben Reviewing District Court Sanctions Imposed for the Purpose of Insuring Compliance witb Pretrial Orders, 29 F.R.D. 420, 421 (1962). 
speech. The very power of these interests, however, requires that they be carefully identified and analyzed, so that they may be confined to appropriate circumstances. This is impossible, however, without the development of a more adequate appreciation of the relationship of law to discretion. Discretion does not simply begin "where the law ends," and for that reason the Court in Rbinebart was deeply misguided in viewing trial court discretion to manage speech as a constitutional carte blanche. 